\title{
EVA BOOLIERIS
}

\section{THIRD-PARTY FUNDING:}

\section{THE EFFECT OF THE GROWING THIRD-PARTY FUNDING INDUSTRY IN INTERNATIONAL ARBITRATION ON NEW ZEALAND}

\author{
Faculty of Law \\ Victoria University of Wellington
}

2015 


\section{TABLE OF CONTENTS}

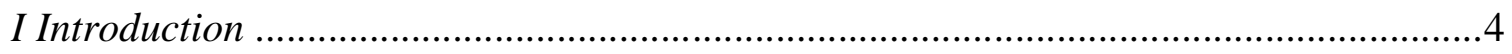

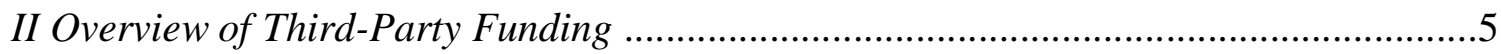

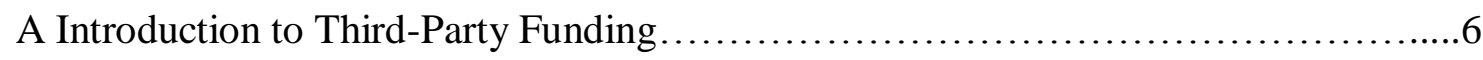

B Benefits and Drawbacks of Third-Party Funding Agreements.....................10

III History of Third-Party Funding and the Main Developments in New Zealand.........12

A History of Third-Party Funding: Maintenance and Champerty $\ldots \ldots \ldots \ldots \ldots \ldots . \ldots 12$

B Third-Party Funding Cases in New Zealand............................... 16

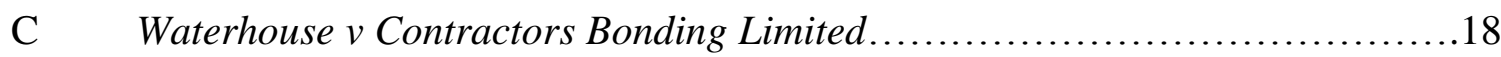

D What is Still to Be Resolved in New Zealand...............................20

IV Third-Party Funding in International Commercial Arbitration ........................22

A Overview of Third-Party Funding in International Arbitration.................22

B Regulation of Third-Party Funding in International Arbitration................23

C Issues in Third-Party Funding in International Arbitration.....................24

1 Overview............................................................. 44

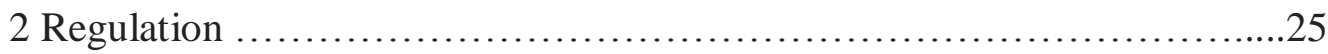

3 Drawing on Domestic Law for Assistance.............................26

4 Issue 1: Disclosure of the Existence of Third-Party Funding $\ldots \ldots \ldots \ldots \ldots \ldots \ldots . \ldots 30$

5 Issue 2: Disclosure of the Details of a Third-Party Funding Agreement.......33

6 Issue 3: Security for Costs and RSM v St Lucia.......................38

7 Issue 4: Costs Awards Against Third-Party Funders.......................51

8 Issue 5: Recovery of Costs by Third-Party Funders.....................53

$V$ Effect of Third-Party Funding in International Commercial Arbitration on New Zealand. 55

A Overview...................55

B The TPPA and Investor Rights....56 
VI Conclusion .

VII Bibliography

66 


\section{Abstract}

The quickly rising trend of third-party funding in international arbitration is an extremely novel and complex challenge for the international arbitration community. Third-party funding has a long history in the law of litigation funding but this new trend will require the international arbitration community to grapple with this concept in a new setting. As domestic countries have taken hugely varying approaches to third-party funding in a litigation context, the international arbitration community has a wealth of choice available to it in deciding how to approach this trend. There are many outstanding issues in this area and there is much speculation as to how these issues will be resolved. New Zealand will be affected by the choices that the international arbitration community makes in this regard when New Zealand engages in international arbitration. The possibility of the TransPacific Partnership Agreement (TPPA) coming into force is also likely to exacerbate some of the effects of the choices made on the state of New Zealand in investor-state arbitration.

\section{Word length}

The text of this paper (excluding abstract, table of contents, footnotes and bibliography) comprises approximately 14,832 words.

\section{Keywords}

Third-Party Funding - International Arbitration - Trans-Pacific Partnership Agreement 


\section{Introduction}

This paper will focus on the emerging trend of third-party funding in international arbitration. This new trend creates complex challenges for the international arbitration community as to the best way to approach it. After setting the context for the discussion, this paper will discuss five of the main challenges in international arbitration to date, how these challenges affect New Zealand and how the proposed TPPA may provide New Zealand with an extra challenge when dealing with third-party funding in international arbitration. This paper will conclude by summarizing the main issues ahead for New Zealand in the realm of third-party funding in international arbitration.

Part II provides a general overview of third-party funding. This includes an introduction to third-party funding and the benefits and drawbacks of third-party funding. Part III describes the history of third-party funding and the main developments in thirdparty funding in New Zealand to date, including the recent decision of Waterhouse $v$ Contractors Bonding Limited ${ }^{l}$ and a discussion on what New Zealand still needs to resolve as to third-party funding. Part II and III focus mainly on the treatment of third-party funding at a domestic, as opposed to an international, level as this is where third-party funding has been explored the most.

Once the context in which the debate about third-party funding in international arbitration takes place has been set, the discussion at the center of this paper can begin. Part IV will focus on the current issues in third-party funding in international arbitration. This part will first provide an overview on third-party funding in the particular context of international arbitration. Second, this part will discuss the five issues around third-party

\footnotetext{
${ }^{1}$ Waterhouse v Contractors Building Limited [2013] NZSC 89.
} 
funding in this context that the international community is grappling with. The overarching issue is whether and how regulation should proceed. The sub issues within this wider issue concern: ${ }^{2}$

(a) Automatic disclosure of the existence of third party funding

(b) Disclosure of the details of a third-party funding agreement

(c) Security for costs awards against third-party funders

(d) Costs awards against third-party funders

(e) Recovery of costs by third-party funders.

Part V will then discuss the effect that any decision as to the above issues will have on New Zealand, with a focus how a combination of third-party funding and the potential conclusion of the Trans-Pacific Partnership Agreement may affect New Zealand's experience in investor-state arbitration.

\section{Overview of Third-Party Funding}

A Introduction to Third-Party Funding

Third-party funding agreements in disputes are a fast-growing trend. ${ }^{3}$ A co-founder of one of the world's largest third-party funders has said that the growth of the third-party funding industry over the last couple of years has been "like night and day". ${ }^{4}$ Third-party litigation funding is an established industry in many countries, and it is becoming more common in New Zealand. ${ }^{5}$ More recently, third-party funding agreements are also gaining

\footnotetext{
${ }^{2}$ Daniel Kaldermis and Paula Gibbs "Third-party funding in international arbitration - lessons from litigation?" 15 Dec 2014 Kluwer Arbitration Blog <http://kluwerarbitrationblog.com>.

${ }^{3}$ Robert Gapes "Litigation Funding" (24 Oct 2012) Simpson Grierson <www.simpsongrierson.com>.

${ }^{4}$ Rebecca Lowe "Investment Arbitration Claims Could Be 'Traded Like Derivatives" 12 March 2013 International Bar Association <http://www.ibanet.org>.

${ }^{5}$ Ibid.
} 
popularity in international arbitration disputes. ${ }^{6}$ Almost all disputes require funding in order to be pursued in a court or an arbitral tribunal to pay for legal costs like lawyers' fees. ${ }^{7}$ Dispute funding is when a third-party funder provides funds so that litigation or arbitration can proceed. ${ }^{8}$ One definition of third-party funding is "a financing method in which an entity that is not a party to a particular dispute funds another party's legal fees or pays an order, award, or judgment rendered against that party, or both". ${ }^{9}$

Professor Catherine Rogers argues that the recent and extensive expansion of thirdparty funding is a "part and parcel of a more global and systematic deregulation of the legal profession". ${ }^{10}$ Rogers' opinion is that this deregulation of legal services has made it more straightforward and more viable for legal claims to be purchased and sold like other investment assets. ${ }^{11}$ Furthermore, the Global Financial Crisis of 2007-2008 put pressure on law firms to invite funding from investment firms that are looking for investments that are not directly influenced by unstable and unpredictable financial markets. ${ }^{12}$ Law firms can invite investment by maximizing their assets, including legal claims. ${ }^{13}$ This practice has led to increased interest from investment firms in legal claims, which has boosted the thirdparty funding industry.

\footnotetext{
6 Ibid.

${ }^{7}$ Christopher Hodges, John Peysner and Angus Nurse "Litigation Funding: Status and Issues" (Jan 2012) University of Oxford Centre for Socio-Legal Studies <www.csls.ox.ac.uk> at 10.

${ }^{8}$ Ibid.

${ }^{9}$ Lisa Bench Nieuwveld and Victoria Shannon Third-Party Funding in International Arbitration (Kluwer Law International, The Netherlands, 2012) at 3.

${ }^{10}$ Catherine Rogers "Gamblers, Loan Sharks \& Third-Party Funders" (Pennsylvania State University and Dickenson School of Law Legal Studies Research Paper No 51-2013) at 3. See also Elizabeth Chan "Funding International Arbitration" [2014] NZLJ 45.

11 Ibid.

12 Ibid.

13 Ibid.
} 
Others see a slightly different correlation between the Global Financial Crisis and the rise of third-party funding. ${ }^{14}$ There might be a link between investment arbitration funders and the 'vulture funds' of the 1990s that purchased the debt of financially stressed states at a low rate and then claimed a much larger rate than the creditor anticipated. ${ }^{15}$ These vulture funds may have sparked the boom of third-party funding:

“There are certainly hedge funds and other entities that are paying close attention to see if there'll be the kinds of opportunities that the sovereign debt crisis in the 90 s presented... The vulture funds that bought the arbitration awards against states [which gave them control over the debt] are in a way what started this. Other investors thought, why wait until there is an award? Why not get involved earlier?"

Whatever the cause of the recent increase in third-party funding, many claimants are not taking advantage of its benefits. The attraction of third-party funding for the claimant is that it allows a claimant to pursue a claim with no risk when the claimant's financial situation may have otherwise prevented them from doing so. ${ }^{16}$ The downside for a claimant is that a for-profit third-party funder will only offer funding in return for an agreed monetary reward, such as a percentage of the amount recovered. ${ }^{17}$ The risk for the funder is that if the funder's client is unsuccessful in the dispute, the funder will generally receive nothing. ${ }^{18}$ The different types of funders include the client's attorney or law firm, an insurance company, or a corporation, bank or other financial institution. ${ }^{19}$ Some of these types of funders are more common in some jurisdictions than others. In countries like

\footnotetext{
${ }^{14}$ Rebecca Lowe, above $\mathrm{n} 4$.

15 Ibid.

${ }^{16}$ Helen Arathimos "Case Note of a Recent Supreme Court Decision on Third Party Litigation Funding: Waterhouse v Contractors Bonding” (2013) YLC Advocate 24 (Spring Edition).

${ }^{17}$ Hodges, Peysner and Nurse, above n 7, at 10.

${ }^{18}$ Gapes, above n 3.

${ }^{19}$ Nieuwveld and Shannon, above n 9, at 4.
} 
Australia where third-party funding is well established, several institutions now specialize in third-party funding. ${ }^{20}$ The United Kingdom also has a thriving legal expenses insurance market. $^{21}$

The type of funder will determine what kind of funding relationship the funder and the client will have. ${ }^{22}$ This paper will focus on the traditional type of third-party funding relationship in international arbitration: non-recourse financing by an institution where repayment is dependent on the client's success in the dispute. ${ }^{23}$ The other four main types of funding relationships are: funding under an insurance policy; attorney financing (pro bono, contingency and conditional fee arrangements); loans; and, assignment of a claim. ${ }^{24}$ The level of control and ownership that the funder has over the dispute depends on the type of funding relationship. ${ }^{25}$ For example, with attorney-financing, a client maintains full control over the dispute as attorneys are bound by professional and ethical rules that require attorneys to act in their client's best interests. ${ }^{26}$ Conversely, in an insurer-insured relationship, the insurance policy may allow the insurance company to have complete or almost complete control over the dispute. ${ }^{27}$ In non-recourse financing, the level of control falls in between these two examples: the institution is not bound by professional or ethical rules but it also does not enjoy the high level of control that an insurance policy gives an insurer. $^{28}$

\footnotetext{
${ }^{20}$ Nieuwveld and Shannon, above $\mathrm{n} 9$, at 4.

${ }^{21}$ Ibid, at 95 and 236.

22 Ibid, at 3.

23 Ibid, at 8 .

${ }^{24}$ Ibid, at 5-8.

${ }^{25}$ Ibid, at 8 .

${ }^{26} \mathrm{Ibid}$, at 6-7.

27 Ibid, at 5.

${ }^{28}$ Ibid, at 8 .
} 


\section{B Benefits and Drawbacks of Third-Party Funding Agreements}

Third-party funding agreements have both their advantages and disadvantages for different players in the dispute resolution process. Describing these advantages and disadvantages serves two main and interrelated purposes. First, it provides context for the discussion of the main issues that the international arbitration community must face in light of the growth of third-party funding in international arbitration. Second, it sets up arguments for why the international arbitration community may want to choose one direction over another when deciding how to tackle these issues.

The main argument for allowing third-party funding is that it gives impecunious parties increased access to justice in the face of rising litigation costs. ${ }^{29}$ Litigation is often dubbed a "rich man's sport": some claimants with meritorious claims simply cannot afford to bring an action. ${ }^{30}$ A party to a dispute in a court or an arbitral tribunal will always require a minimum amount of funds to initiate a claim, pay expert witnesses and prove damages. ${ }^{31}$ Third-party funding has the possibility to allow more meritorious claims to be heard.

However, the benefits of third-party funding to access to justice can be overstated. Commercial litigation funders will not support claims on their merits; funders will probably only support claims where the anticipated return is enough to offset litigation costs and the risk of an unsuccessful claim. ${ }^{32}$ Moreover, defendants cannot take advantage of litigation

\footnotetext{
${ }^{29}$ Nieuwveld and Shannon, above n 9, at 62.

${ }^{30}$ Reuben Guttman "Litigation is a Rich Man's Game: Finding Justice and Politics of Personalisation" (25 Feb 2014) <www.ibtimes.co.uk>.

${ }^{31}$ Nieuwveld and Shannon, above n 9, at 62.

${ }^{32}$ Waterhouse v Contractors Building Limited, above n 1, at [41].
} 
funding except for through insurance. ${ }^{33}$ Evidence suggests that third-party funders are otherwise very unlikely to invest in defence claims. ${ }^{34}$ Defendants who are faced against a plaintiff who is receiving backing from a third-party funder may therefore have to prematurely settle due to a lack of resources. ${ }^{35}$

Another concern in third-party funding is that, in class actions, funders will often want a commission from all of the class action members in a class action settlement. ${ }^{36}$ Funders will therefore also want a commission from those group members who have not signed a funding contract themselves. ${ }^{37}$ This will mean that the court will enforce funding on group members as a condition, as opposed to funding being a contractual agreement that parties have voluntarily signed up for. ${ }^{38}$

Another benefit is that involvement of a third-party funder with commercial expertise may mean that the litigation is carried out more proficiently, with more consideration of the possible risks and benefits of the litigation. ${ }^{39}$ However, a commercial law firm that is acting for the client could probably carry out an assessment of the risks and benefits of the litigation as efficiently as a third-party funder as a commercial law firm will also have commercial expertise.

There are also concerns that the third party may attempt to control the litigation in a way that frustrates the proceedings for his or her benefit, for example by inflating

\footnotetext{
${ }^{33}$ Ibid, at [42].

${ }^{34}$ Elizabeth Chan "Funding International Arbitration" [2014] NZLJ 45.

${ }^{35}$ Waterhouse v Contractors Building Limited, above n 1, at [42].

${ }^{36}$ Ben Bigby and Angela Bilbow "Storm Clouds Rising” 11 Dec 2014 Commercial Dispute Resolution <http://www.cdr-news.com>.

${ }^{37}$ Ibid.

38 Ibid.

${ }^{39}$ Waterhouse v Contractors Building Limited, above n 1, at [43].
} 
damages. ${ }^{40}$ For this reason, lawyers who have clients who are supported by third-party funders may compromise their independence due to feeling like they have a responsibility to act not only for their client but also for the third-party funder. ${ }^{41}$

There are futher concerns that third-party funding of claims may increase disputes. $^{42}$ This may exacerbate the problem of frivolous litigation that already exists in some jurisdictions. While this problem is not as prevalent in New Zealand, this concern has created a large opposition to third-party funding in the United States, which has been named "the world's most litigious society". ${ }^{43}$ The US Chamber of Commerce has argued that third-party litigation funding has increased the amount of unworthy claims as funders are content to stake funds on "weak" cases that have the potential to reap a big reward. ${ }^{44}$

\section{History of Third-Party Funding and the Main Developments in New}

\section{Zealand}

A History of Third-Party Funding: Maintenance and Champerty

Third-party funding has not always been legal in all jurisdictions. For a long time, the common law rejected the practice. ${ }^{45}$ Providing a history of third-party funding adds two contextual points to the discussion of the issues that the international arbitration community faces with regard to third-party funding in the present day. The first point is that some of the original suspicions that arose when third-party funding was introduced have survived until the present day. Domestic countries that are more suspicious of third-party funding

\footnotetext{
40 "Storm Clouds Rising", above n 36.

${ }^{41}$ Rebecca Lowe, above $\mathrm{n} 4$.

${ }^{42}$ Nieuwveld and Shannon, above n 9, at 63.

${ }^{43}$ Ibid.

${ }^{44}$ Rebecca Lowe, above $\mathrm{n} 4$.

${ }^{45}$ Nieuwveld and Shannon, above n 6, at 40.
} 
are likely to either enforce tighter controls on third-party funding or to ban the practice. As the international arbitration community will probably draw on or at least gain some inspiration from domestic laws if it intends to regulate third-party funding, it is possible that a hangover of these suspicions may become part of the regulation of third-party funding in international arbitration. The second point is that detailing the history of how different domestic countries have treated third-party funding gives insight into why the international arbitration community now allows third-party funding: over the years it has simply become more and more common.

At common law, third-party funding originally amounted to committing the torts of maintenance and champerty. ${ }^{46}$ Maintenance is "the funding or providing of financial assistance to a holder of a claim, which allows the claim to be legally pursued when the funder or provider of financial assistance holds no connection or valid interest in the claim itself" ${ }^{47}$ Champerty was historically considered to be an especially "obnoxious" type of maintenance. $^{48}$ Champerty has the added requirement that the funder or financial assistance provider offers the funding in return for a share of the damages if the claim is successful. ${ }^{49}$ In nineteenth century Britain, maintenance and champerty were against the law because they were held to morally and ethically contravene public policy and both civil and criminal penalties would ensue from committing one of these torts. ${ }^{50}$ These torts

\footnotetext{
${ }^{46}$ Nieuwveld and Shannon, above n 9, at 40.

47 Ibid.

${ }^{48}$ Sean McAnally "Litigation Funding” (2012) NZLJ 361. See also Trendex Trading Corporation v Credit Suissee [1980] [1980 QB 629; [1981 3 All ER 520; 19813 WLR 766 at 654 (CA).

${ }^{49}$ Nieuwveld and Shannon, above n 9, at 40.

50 Ibid.
} 
existed to combat a perceived risk that a litigation funder might undermine court processes, for example by suborning witnesses or exploiting valueless claims. ${ }^{51}$

Even now, some academics have suggested that people still believe that there is something suspicious about permitting a funder to benefit from a client's dispute. ${ }^{52}$ These suspicions may be greater in jurisdictions like the United States, where the funder and the plaintiff's law firm generally receive a far greater share of the proceeds than the claimants themselves. ${ }^{53}$ Nevertheless, the modern approach to maintenance and champerty is more liberal. The main reason for a more liberal approach is that modern courts are perceived to be less susceptible to the "mischief" that the doctrines of maintenance and champerty were designed to protect against, namely the undermining of court processes. ${ }^{54}$

However, while some jurisdictions have abolished these torts, these torts still remain a part of the law in other jurisdictions. In the United Kingdom, the legislature has expressly removed the torts of maintenance and champerty in all areas but one. ${ }^{55}$ Under United Kingdom law, a contract can be unenforceable if it contravenes public policy, and maintenance and champerty can be grounds for arguing that a contract violates public policy. ${ }^{56}$ In Australia, four of its eight jurisdictions also do not recognize these torts any longer. ${ }^{57}$ In the jurisdictions where maintenance and champerty are still theoretically illegal, litigation funding is presumed not to be invalid. ${ }^{58}$ Like in the United Kingdom, in

\footnotetext{
${ }^{51}$ McAnally, above $\mathrm{n} 48$.

${ }^{52}$ Catherine Rogers "Gamblers, Loan Sharks \& Third Party Funders, above n 10, at 2-3.

${ }^{53}$ Helen Arathimos, above n 16.

${ }^{54}$ Belinda Barclay "Litigation Funding: Coming to A Court Near You" (2008) Lawlink <www.lawlink.co.nz>.

${ }^{55}$ Nieuwveld and Shannon, above n 9, at 40. Sections 13 and 14 of the Criminal Law Act of 1967 removed both the crimes and torts of maintenance and champerty.

${ }^{56}$ Ibid, at 41. See Criminal Law Act (UK), s 14(2).

${ }^{57}$ Ibid, at 42 .

${ }^{58}$ Ibid.
} 
all Australian jurisdictions maintenance and champerty can be relevant to ascertaining whether a contract is unenforceable because it contravenes public policy or it is an abuse of process, although there is a high standard of proof. ${ }^{59}$

In New Zealand, the torts of maintenance and champerty have not been expressly removed from the law. ${ }^{60}$ In Waterhouse $v$ Contractors Bonding, counsel for the Waterhouses argued that the torts of maintenance and champerty should be abolished. ${ }^{61}$ However, the Supreme Court said it would be inappropriate to make a ruling on these torts in the case at hand because evidence concerning these torts was not before the court. ${ }^{62}$ It can therefore be deduced that the Supreme Court presumed their ongoing existence. ${ }^{63}$

However, there have been judicial statements holding that in one of the most important New Zealand cases on maintenance and champerty, the court noted that:

\footnotetext{
"There has been a dramatic change in attitude, with some jurisdictions abolishing the tort of champerty altogether and Courts generally adopting a much more liberal and relaxed approach, to the point where many authorizes appear actively to support litigation funding as a matter of public policy".
}

Building on this "relaxed" approach, the court held that the mere existence of maintenance or a champertous agreement is not enough in itself to constitute an abuse of process. ${ }^{64}$ Therefore there is a common theme in these jurisdictions that, whether maintenance and champerty have been abolished or not, these doctrines are no longer causes of actions in

\footnotetext{
${ }^{59}$ Ibid, at 42 .

${ }^{60}$ McAnally, above n 48; Saunders v Houghton [2009] NZCA 610, [2010] 3 NZLR 331 at [67].

${ }^{61}$ Waterhouse v Contractors Building Limited, above n 1, at [14].

${ }^{62} \mathrm{Ibid}$, at [26].

${ }^{63}$ Ibid.

${ }^{64}$ Saunders $v$ Houghton, above n 60, at [67].
} 
themselves; these doctrines can only be used to argue that another cause of action, such as contravention of public policy or an abuse of process, is proved.

\section{B Third-Party Funding Cases in New Zealand}

Illustrating New Zealand's current experience with third-party funding at a domestic level is useful for two reasons. First, it helps in gauging what background of third-party funding that the state of New Zealand is likely to have before entering into an international arbitration where third-party funding is involved. Further, as the international arbitration community is likely to draw on domestic law in any regulation that it promulgates to address the current issues in third-party funding, this section also gives an example of some of the many directions that the international arbitration community could follow.

Third-party litigation funding exists in New Zealand, although it is said to be "still in the early stages of adolescence". ${ }^{65}$ Third-party litigation funding is being discussed in this paper because third-party funding in international arbitration is generally considered to be a "close cousin" of litigation funding, even though third-party funding in international arbitration has some subtle differences from third-party funding in litigation. ${ }^{66}$ To date, New Zealand has not yet been involved in an international arbitration in which one party is being funded by a third party funder. There is extremely scarce, if any, research that has been done into how much the law of third-party funding in litigation will influence any emerging laws on third-party funding in international arbitration. ${ }^{67}$ However, a description of the current New Zealand approach to third-party funding provides a background to the

\footnotetext{
${ }^{65}$ McAnally, above n 48.

66 Nieuwveld and Shannon, above n 9, at 3.

${ }^{67}$ Ibid, at preface.
} 
attitudes of third-party funding in New Zealand and completes the view of the domestic landscape from which the state of New Zealand will be coming from when it eventually participates in third-party funding in international arbitration.

New Zealand's litigation finance industry is not as developed as the industries in many other jurisdictions, including the United Kingdom and Australia. ${ }^{68}$ Australia is sometimes labeled "the most funding-friendly jurisdiction in the world" due to its number of highly experienced funders, well-informed courts and rather lenient regulations. ${ }^{69}$ The United Kingdom is the jurisdiction in which the doctrines of champerty and maintenance were formed, and it has also collected a vast amount of case law and commentary on thirdparty funding since. ${ }^{70}$

Conversely, in New Zealand, the law on third-party funding has largely been on a case-by-case basis. ${ }^{71}$ The limited amount of case law means that there are still many uncertainties in this area of law. This uncertainty is unlikely to be resolved by the courts in the near future as the New Zealand Supreme Court has recently held that "it is not the role of the courts to act as general regulators of litigation funding arrangements. If that is considered desirable, it is a matter for legislation or regulation". ${ }^{72}$

The first instances of third-party funding in New Zealand occurred in liquidation cases in the early 2000s. ${ }^{73}$ The next major development was the Houghton v Saunders line of cases, where both the trial court and the Court of Appeal affirmed that third-party

${ }^{68}$ Elizabeth Chan "Funding International Arbitration", above n 10.

${ }^{69}$ Nieuwveld and Shannon, above $\mathrm{n} 9$, at 71 .

${ }^{70}$ Ibid, at 95 .

${ }^{71}$ Helen Arathimos, above n 16.

${ }^{72}$ Waterhouse v Contractors Building Limited, above n 1, at [28].

${ }^{73}$ Sean McAnally "Litigation Funding" (2012) NZLJ 361. The liquidation cases are Re Nautilus Developments Ltd (in liquidation) [2000] 2 NZLR 505, (2000) 8 NZCLC 262,235 and Re Gellert Developments Ltd (in liquidation) (2001) 9 NZCLC 262,714. 
funding agreements are lawful. ${ }^{74}$ In the High Court, the defendants applied for a stay of proceedings, alleging that the funding agreement was champertous and an abuse of process. ${ }^{75}$ The Court listed factors relevant to whether there is an abuse of process, and found that this was not the case here. ${ }^{76}$ These factors were:

a) The degree of control that the funder has over the litigation;

b) Whether the funder stands to gain an excessive or disproportionate profit;

c) Whether the funder is not merely providing funding but has in fact instigated the proceedings; and

d) Whether the funder is a stranger to the dispute and does not seek to resolve the matter to achieve justice but rather to make a profit. ${ }^{77}$

On appeal, Court of Appeal ruled that it can order a litigation funder to give security for costs under section 15 of the Judicature Act $1908 .{ }^{78}$ On appeal in the High Court, it was held that the plaintiff did not have to reveal the full terms of the funding agreement to the defendant, although the plaintiff may have to do so to the court. ${ }^{79}$

\section{Waterhouse v Contractors Bonding Limited}

The most recent case is the Supreme Court decision Waterhouse $v$ Contractors Bonding Limited. ${ }^{80}$ The Waterhouses were suing Contractors Bonding Ltd in regard to an unsuccessful insurance venture. ${ }^{81}$ Waterhouse differed to Houghton $v$ Saunders in the important respect that it was not a representative action; the Supreme Court specifically

\footnotetext{
${ }^{74}$ Nieuwveld and Shannon, above n 9, at 62 and 235; Saunders v Houghton, above n 60.

${ }^{75}$ Sean McAnally, above n 55, at 361.

${ }^{76}$ Saunders v Houghton, above n 60.

${ }^{77}$ Ibid.

${ }^{78}$ Sean McAnally, above n 55, at 235. Houghton v Saunders; Saunders v Houghton [2009] NZCA 610, [2010] 3 NZLR 331.

${ }^{79}$ Nieuwveld and Shannon, above n 6, at 235.

${ }^{80}$ Waterhouse v Contractors Building Limited, above $\mathrm{n} 1$.

${ }^{81}$ Ibid, at [1].
} 
held that it was not passing judgment on the Court's stance to third-party litigation funding in a representative action. ${ }^{82}$ The issue in this appeal was "whether the Waterhouses should be ordered to disclose the litigation funding agreement to Contractors Bonding and, if so, on what terms". ${ }^{83}$ Both the High Court and the Court of Appeal had required disclosure of the funding agreement. The High Court held that the agreement need only be disclosed to the court. ${ }^{84}$ Conversely, the Court of Appeal held that a redacted version of the agreement that showed the principle terms should be disclosed to the other side. ${ }^{85}$

In the Supreme Court, counsel for the Waterhouses argued that courts should only concern themselves with litigation funding agreements that are an abuse of process. ${ }^{86}$ Conversely, counsel for Contractors Bonding submitted that the defendant does not need to show that tortious conduct has occurred before courts can have supervisory control over litigation funding agreements, and that a party should disclose the presence and terms of a litigation funding agreement at the outset of proceedings. ${ }^{87}$

The Court concluded that, in this proceeding, some of the terms of the funding arrangement had to be disclosed to both the court and to the other party. ${ }^{88}$ However, whether disclosure was required and what terms would be required to be disclosed would depend on whether the non-funded party has made an application to which the terms of the funding agreement are pertinent. ${ }^{89}$ Disclosure was required here because the Contractors Bonding had filed an application for security for costs, and certain terms of the agreement

\footnotetext{
${ }^{82}$ Waterhouse v Contractors Building Limited, above n 1, at [24].

${ }^{83}$ Ibid, at [2].

${ }^{84}$ Waterhouse v Contractors Bonding Limited HC Auckland CIV-2010-404-3074, 13 December 2010.

${ }^{85}$ Contractors Bonding $v$ Waterhouse [2012] NZCA 399; [2012] 3 NZLR 826 (CA).

${ }^{86}$ Waterhouse v Contractors Bonding Limited, above n 1, at [14].

${ }^{87}$ Ibid, at [19].

${ }^{88}$ Waterhouse v Contractors Bonding Limited, above n 1, at [73].

${ }^{89}$ Ibid.
} 
were relevant to this application. ${ }^{90}$ A more in-depth discussion of the disclosure requirements that this case set out will be found below in the discussion of whether disclosure of the terms of a funding agreement is likely to be required in international arbitration.

D What is Still to Be Resolved in New Zealand?

Though Waterhouse $v$ Contractors Bonding has shed more light on the New Zealand position as to third-party funding, more clarification is desirable. First, the Supreme Court in Waterhouse v Contractors Bonding was careful to say that it was not commenting on representative actions, although Saunders $v$ Houghton may provide some guidance in such a case. ${ }^{91}$ At first instance, the Houghton $v$ Saunders case, also known as the Feltex lawsuit, has been called "a sobering example of the need for careful regulation in this area". ${ }^{92}$ Harbour Litigation Funding funded the Feltex lawsuit and allowed four thousand investors to take action for the recovery of NZD 185 million against the Feltex directors. ${ }^{93}$ The significant amount of money involved in this dispute has prompted further comments that "[c]lass action regulation ought to facilitate class actions in appropriate cases while also providing for effective controls on exorbitant use of the procedure. In order to do so, regulation needs to address the role of litigation funders". ${ }^{94}$ Thus some members of the legal profession do not think that the guidelines even for class actions are sufficient, and Waterhouse did not add anything in this regard.

\footnotetext{
${ }^{90}$ Waterhouse v Contractors Bonding Limited, above n 1, at [76].

${ }^{91}$ Ibid, at [24].

92 "Storm Clouds Rising”, above n 36.

93 Ibid.

94 Ibid.
} 
A second issue that the Supreme Court in Waterhouse left unclarified is the appropriate level of control, if any, of funders over the litigation, or the suitable level of profit that the funder can make from a successful claim. ${ }^{95}$ In this regard the Court held that it is not its role to determine the reasonableness of any funding agreement. ${ }^{96}$ Moreover, it seems unlikely that the courts will clarify these issues in the near future. As above, the Supreme Court considered it the role of the legislature, and not the courts, to regulate litigation funding agreements. ${ }^{97}$

The New Zealand legislature has turned its mind to the issues surrounding litigation funding but no legislation has yet resulted. The Rules Committee has produced a draft Class Actions Bill and draft High Court Amendment (Class Actions) Rules, which would become the new Part 34 of the current High Court Rules. ${ }^{98}$ These proposals envisaged that litigation funding agreements "must unquestionably be subject to judicial scrutiny and possible disapproval". 99 The equivalent Australian legislation has largely influenced these proposals. ${ }^{100}$ There was no influence from the United Kingdom as the United Kingdom does not permit class actions, and instead allows Group Litigation Orders, which are different to class actions in that the all class members must actively partake in the action. ${ }^{101}$

However, the problem is that there has been no significant progress made since the draft Bill and the draft Rules were produced in 2008. ${ }^{102}$ These 2008 drafts are still sitting

\footnotetext{
95 Robert Gapes "Litigation Funding”, above n 3.

${ }^{96}$ Waterhouse v Contractors Bonding Limited, above n 23, at [48].

${ }^{97}$ Waterhouse v Contractors Bonding Limited, above n 23, at [48].

${ }^{98}$ Rules Committee Class Actions for New Zealand (Rules Committee, A Second Consultation Paper, Oct 2008).

${ }^{99}$ Ibid, at 10.

${ }^{100}$ Rules Committee, above n 98, at 1 .

101 Ibid, at 4.

102 Robert Gapes, above n 3.
} 
with the Ministry of Justice. ${ }^{103}$ Commentators have labeled the failure of the Class Actions Bill to make it to Parliament a "mistake", because legislation gives both certainty and a user-friendly outline of the law for plaintiffs who are lay people and also for the litigation funders themselves, as "uncertainty is a deterrent to investment". ${ }^{104}$

Moreover, in these proposals the legislature does not address third-party funding in proceedings other than class actions, as "other proceedings involve wider considerations". ${ }^{105}$ These proposals would therefore not have been any help in a case like Waterhouse v Contractors Bonding, which did not concern a class action, and are therefore only a very limited solution to producing legal certainty in third-party funding in New Zealand.

\section{Third-Party Funding in International Commercial Arbitration}

\section{A Overview of Third-Party Funding in International Arbitration}

Third-party funding is quickly infiltrating the international commercial arbitration sphere. Professor Catherine Rogers states that this is because funders find international arbitration cases attractive because the evidentiary costs may be lower, the proceedings are often quick, there is generally more control over arbitration proceedings than there is in litigation proceedings, arbitral awards are generally very enforceable and there are a lot of high-value claims. ${ }^{106}$ These high-value claims are especially prevalent in investor-state

\footnotetext{
${ }^{103}$ Robert Gapes, above n 3.

104 "Storm Clouds Rising", above n 36.

105 Rules Committee, above n 98, at 10.

106 Catherine Rogers, above n 7, at 6. See also Elizabeth Chan, above n 10.
} 
arbitration cases as a funder may recover a substantial sum of money from a state in these claims. $^{107}$

Some of the drawbacks of third-party funding in general that were emphasized above are exacerbated in the case of third-party funding in the context of international commercial arbitration. Professor Rogers voices concerns that the presence of third-party funders in the international commercial arbitration sphere will create a rise in the number of arbitration cases brought against states in investor-state arbitration. ${ }^{108}$ The increasing number of cases against states is an issue because third-party funders are less likely to want to fund states. ${ }^{109}$ Although there is no technical reason why a state cannot be funded by a third-party funder in investor-state arbitration, evidence suggests that funders seldom agree to invest in a defence claim. ${ }^{110}$ Moreover, even if a third-party funder agrees to fund a state in investor-state arbitration, this is a very contentious move for a state due to the potential conflict between the state's obligations to its public and the possibility that the third-party funder may try to control the proceedings to some extent. ${ }^{111}$

\section{B Regulation of Third-Party Funding in International Arbitration}

Third-party funding in international investment arbitration is currently unregulated. ${ }^{112}$ The growing availability of assistance from third-party funders for highvalue claims in international arbitration has been recognized as a contributor to rising levels

\footnotetext{
${ }^{107}$ Elizabeth Chan, above n 10.

${ }^{108}$ Catherine Rogers, above n 10, at 7. See also Elizabeth Chan, above n 10.

${ }^{109}$ Elizabeth Chan, above n 10.

110 Ibid.

111 Ibid.

112 Rebecca Lowe, above n 4.
} 
of particular types of arbitration, like investment treaty claims. ${ }^{113}$ The increasing number of arbitration proceedings has not been welcomed by all countries around the world: in fact, Argentina's threats to leave the International Centre for Settlement of Investment Disputes have been attributed to the rise in some types of arbitration. ${ }^{114}$ Due to the increase in arbitration proceedings as a result of third-party funding, arbitral institutions have begun to debate whether new rules might be needed to regulate certain aspects of third-party funding in international arbitration. ${ }^{115}$

\section{Issues in Third-Party Funding in International Arbitration}

\section{Overview}

As stated above, the emergence of third-party funding in the realm of international arbitration creates challenges. The main issues that the international arbitration community must face are described in more detail below:

1. Is automatic disclosure of the existence of third party funding required?

2. In what circumstances, if any, must the details of the third party funding agreement be disclosed?

3. Can, and if so when should, a tribunal order security for costs against third party funders?

4. Can, and if so when should, a tribunal award costs against third party funders?

5. Can third party funders recover their costs as part of a costs award? ${ }^{116}$

This section will first discuss the debate for regulation of third-party funding in international arbitration and outline the views of some commentators who believe that

\footnotetext{
113 Jonathan Wood and Daniel Hemming "Third-Party Funding of Litigation: A Perspective On The International Landscape" Oct $2014<$ http://whoswholegal.com>.

114 Ibid.

115 Ibid.

${ }^{116}$ Daniel Kaldermis and Paula Gibbs, above n 2.
} 
domestic law can be used as a model for regulating third-party funding at an international level. Then the above questions above will be canvassed in more detail.

\section{Regulation}

Regulating third-party funding in international arbitration would increase certainty in the area. Whether more regulation is introduced into the realm of thirdparty funding in international arbitration will affect the climate in which New Zealand will have to deal with investors in investor-state arbitration. That third-party funding is here to stay in international arbitration was made clear in the recent ICSID tribunal decision Giovanni Alemanni $v$ The Argentine Republic. ${ }^{117}$ In Alemmani, the three renowned and high-profile international arbitrators on the panel made the following statement on third-party funding:

"the practice is by now so well established both within many national jurisdictions and within international investment arbitration that it offers no grounds in itself for objection". ${ }^{118}$

The more realistic question now, then, is not whether third-party funding should be an option. Rather, seeing as third-party funding is an option for many claimants today, the main question is: should third-party funding in international arbitration be regulated? Further, if so, how should it be regulated?

${ }^{117}$ Giovanni Alemanni and others v. Argentine Republic (ICSID Case No. ARB/07/8)

${ }^{118}$ Ibid; Christopher Bogart "Third Party Funding in Action: Alemanni v Argentina" 15 Jan 2015 $<$ http://www.burfordcapital.com>. 
3 Drawing on Domestic Law for Assistance

Some commentators have suggested that the international arbitration community may be able to draw on domestic law to assist with regulation. ${ }^{119}$ However, though many domestic courts have considered these issues at length, many domestic courts have differing opinions. ${ }^{120}$ This lack of consensus means the international arbitration community will have to weigh up its options; drawing on domestic law will not be a matter of simply applying domestic principles to international law.

The discrepancy between domestic courts has caused some commentators to question whether domestic law can actually be useful at an international level at all. ${ }^{121}$ However, the other argument is that the dissimilar domestic case law shows a "conceptual struggle" as to how to perceive third-party funders and that domestic law is therefore valuable to the international community, which also needs to decide how third-party funders will be perceived in a legal context. ${ }^{122}$

To draw on domestic law, the international arbitration community must first ascertain what that domestic law is. Domestic countries fall on a spectrum that, at one end, views third-party funding as a valid method of funding an arbitration proceeding. ${ }^{123}$ This is a "market-oriented approach", as it considers that the financial market can fund legal claims, just like it would any other asset. ${ }^{124}$ This means that

\footnotetext{
${ }^{119}$ Daniel Kalderimis and Paula Gibbs, above n 2.

${ }^{120}$ Ibid.

${ }^{121}$ Ibid.

${ }^{122}$ Ibid.

${ }^{123}$ Ibid.

124 Ibid.
} 
claimants in need of extra funding can approach the market and join with a third-party funder in order to have their claim heard. ${ }^{125}$ The main rationale for this "marketoriented approach" is access to justice, which has been canvassed in more detail above. $^{126}$

At the other end of this spectrum, some domestic countries view third-party funding as invalid. ${ }^{127}$ This is a "true claimant approach". ${ }^{128}$ This approach holds that, in disputes, there must be a 'true claimant' that needs to either pursue, or not pursue, its own claims. ${ }^{129}$ This approach still sees some logic in the previously described torts of maintenance and champerty, which condemn the provision of financial assistance for a claim where the financial assistance provider has no interest in the claim. ${ }^{130}$

The international arbitration community may be able to extract useful information out of these two approaches by recognizing that both approaches lend to different procedural decisions. ${ }^{131}$ For example, the "true claimant" approach tends to lead to courts and tribunals closely monitoring any instance of third-party funding and strict requirements that third-party funding agreements must comply with certain regulations developed in that country. ${ }^{132}$ On this approach, where a third-party funder acts improperly, it is likely that security for costs or a stay of proceedings may be ordered. ${ }^{133}$ New Zealand fits within the "true claimant" approach group. ${ }^{134}$

\footnotetext{
${ }^{125}$ Daniel Kalderimis and Paula Gibbs, above $\mathrm{n} 2$.

126 Ibid.

127 Ibid.

128 Ibid.

129 Ibid.

${ }^{130}$ Ibid.

131 Ibid.

132 Ibid.

133 Ibid.
} 
Conversely, countries that take a more "market-oriented" approach to thirdparty funding consider a third-party funder to be more of a "shadow co-claimant". 135 The result of this perception is that the court or tribunal will not examine the funding agreement between the claimant and the third-party funder. ${ }^{136}$ However, unlike in the "true claimant" approach, the court or tribunal may need to make orders against the funder directly. ${ }^{137}$ The result of the third-party funder being recognized as part of the proceedings then is that funders must also accept the related responsibilities. ${ }^{138}$

Some argue that the "true claimant" model is the best model for the international arbitration community to draw on as inspiration for regulating third-party funding. ${ }^{139}$ There are problems with applying the "market-oriented" approach to international arbitration, even though it may be appealing to do so due to the fact that arbitration itself is a market-based system. ${ }^{140}$ The system is constrained by its contractual base, which demands that any claimant must be a party to the arbitration agreement that is made against any respondent. ${ }^{141}$ Thus the "market-oriented" model's main instrument is the ability to order costs directly against third-party funders. ${ }^{142}$ But, if this is unavailable, the benefits of the "market-oriented" model seem to be diminished. ${ }^{143}$

\footnotetext{
${ }^{134}$ Daniel Kalderimis and Paula Gibbs, above n 2.

135 Ibid.

${ }^{136}$ Ibid.

${ }^{137}$ Ibid.

${ }^{138}$ Ibid.

${ }^{139}$ Ibid.

${ }^{140}$ Ibid.

${ }^{141}$ Ibid.

${ }^{142}$ Ibid.

${ }^{143}$ Ibid.
} 
Thus the "true claimant" model may be more beneficial. ${ }^{144}$ The increased regulation in international arbitration that would follow from adopting a model closer to the "true claimant" model will probably decrease the likelihood of jurisdictional issues in the future. ${ }^{145}$ Further, to placate the international legal community, international arbitration could adopt a less stringent form of the "true claimant" model than many domestic countries have adopted. ${ }^{146}$ While many Commonwealth countries, such as New Zealand, have been influenced by the historical torts of maintenance and champerty that originated in the United Kingdom, international arbitration is not affected by these common law torts. ${ }^{147}$ This will allow international arbitration tribunals to formulate rules and regulations free of any cumbrances.

In sum, regulation is desirable. Domestic courts can give the international arbitration community guidance on how to go about regulating the use of third-party funding in international arbitration, and the international arbitration community will benefit from adopting certain characteristics of the "true model" that certain domestic countries follow. In the meantime, tribunals should use their resources in a way that protects parties from unfairness due to the existence of a third-party funder. ${ }^{148}$ To maintain fairness and equality, commentators urge that tribunals keep grappling with the current issues in third-party funding in international arbitration that are detailed below.

\footnotetext{
${ }^{144}$ Daniel Kalderimis and Paula Gibbs, above $\mathrm{n} 2$.

145 Ibid.

146 Ibid.

147 Ibid.

148 Ibid.
} 


\section{Issue 1: Disclosure of the Existence of Third-Party Funding}

One controversial issue in international arbitration is whether a party receiving third-party funding should have to disclose this fact to the other party in the arbitration proceedings. ${ }^{149}$ This issue has been somewhat resolved by the International Bar Association's 2014 revisions to its 2004 'Guidelines on Conflicts of Interest in International Arbitration'. ${ }^{150}$ General Standard 6(b), 'Relationships', holds that:

"[i]f one of the parties is a legal entity, any legal or physical person having a controlling influence on the legal entity, or a direct economic interest in, or a duty to indemnify a party for, the award to be rendered in the arbitration, may be considered to bear the identity of such party". ${ }^{151}$

The 'Explanation to General Standard 6' clarifies that 'third-party funders and insurers in relation to the dispute may have a direct economic interest in the award, and as such, may be considered to be the equivalent of that party". ${ }^{152}$ This means that claimants who use third-party funding must now disclose their use of third-party funding to the tribunal and to other parties to the arbitration. ${ }^{153}$

Before the International Bar Association's 2014 revisions, there were still some instances in which third-party funders were required to disclose their existence, but these were few and far between. ${ }^{154}$ For example, if a third-party funder was funding a claimant

\footnotetext{
${ }^{149}$ Daniel Kaldermis and Paula Gibbs, above $\mathrm{n} 2$.

150 "Third-Party Funding in Arbitration" Nov 2014 Australian International Disputes Centre <www.disputescentre.com.au>.

${ }^{151}$ IBA Guidelines on Conflicts of Interest in International Arbitration (2014) International Bar Association, 23 Oct $2014<$ http://www.ibanet.org>.

152 Ibid.

153 “IBA Guidelines and Rules" New Zealand Dispute Resolution Centre < www.nzdrc.co.nz>.

${ }^{154}$ Nieuwveld and Shannon, above n 9, at 26.
} 
that was a listed company on the public stock exchange, and the litigation funding agreement constituted a material transaction for that company, then the third-party funder had to disclose its existence. ${ }^{155}$

General Standard 6(b) has three main ramifications. First, parties will gain more knowledge as to the other party's capability to finance the arbitration. ${ }^{156}$ Some commentators think that this increased knowledge may give the other party an incentive to settle as opposed to pursuing the proceedings as it suggests that "an independent third party has investigated and formed a favourable view as to the merits of the claim. ${ }^{157}$ The presence of a third-party funder is even more likely to encourage that other party to settle if that funder is well-known and respected. ${ }^{158}$ Second, third-party funders are much more likely to be directly engaged in the proceedings. ${ }^{159}$ This involvement is likely to occur if the other party to the arbitration either requests an award for security for costs against a third-party funder or the tribunal imposes a costs award that is also enforceable against the third-party funder. ${ }^{160}$ Thirdly, as the International Bar Association Guidelines that are mentioned above attempt to address, disclosure of a third-party funder allows actual or potential conflicts of interests to be identified and dealt with appropriately. ${ }^{161}$

However, arguments against disclosure include that if an arbitrator does not know that a third-party funder is involved in the proceeding, then the existence of a third-party funder can have no effect on the arbitrator's final decision so there is no need to address

\footnotetext{
155 Nieuwveld and Shannon, above n 9, at 26.

156 "IBA Guidelines and Rules", above n 153.

157 Ibid.

158 IBA Guidelines on Conflicts of Interest in International Arbitration (2014), above n 151.

159 "IBA Guidelines and Rules", above n 153.

160 Ibid.

161 Ibid.
} 
any actual or potential conflicts of interest. ${ }^{162}$ Another argument is that third-party funders have in the past been wary of disclosing their existence as this disclosure may provoke the other party to instigate distracting satellite litigation or ancillary applications to the tribunal. $^{163}$

The current position at an international level under the International Bar Association's Guidelines is similar to the position in New Zealand's domestic law. The Waterhouse case, discussed above, found that in certain applications, such as for security for costs, the funded party will probably have to disclose the identity and location of the third-party funder and how amenable the funder is to the jurisdiction of the New Zealand courts. ${ }^{164}$ The New Zealand Supreme Court did not offer any jurisdictional basis for this ruling but merely reasoned that disclosing the presence of a funder lets the court and the other parties see the "real parties" to the proceedings. ${ }^{165}$ The concept is not foreign in New Zealand law: the requirement of disclosure of third-party funders has been compared to legal aid, where there is also a requirement of disclosure that a party is being funded by legal aid. ${ }^{166}$ Australia also has the same position: the Federal Court's Practice Note CM 17 states that parties using third-party funding must disclose this fact to the court and to the other parties before or during the initial case management conference. ${ }^{167}$ This then is one example of how international law has aligned with some domestic laws.

\footnotetext{
${ }^{162}$ Nieuwveld and Shannon, above $\mathrm{n} 9$, at 26.

${ }^{163}$ Ibid.

${ }^{164}$ Waterhouse v Contractors Bonding Limited, above n 1, at [76].

${ }^{165}$ Chris Browne and Felicity Monteiro "Supreme Court mandates disclosure of litigation funding agreements" Wilson Harle 10 Dec 2013 < www.wilsonharle.com>.

166 Ibid.

${ }^{167}$ Nieuwveld and Shannon, above n 9, at 60-61.
} 
The required disclosure of a funding agreement in international law will allow the state of New Zealand to be informed of what it is up against in investor-state arbitration. An investor being funded by a third-party funder may signal to New Zealand that the investor has a good case as a professional third-party funder has assessed the case and concluded that it is a good investment. Knowledge of the involvement of a third-party funder may also signal to New Zealand that the case could go on for a long time as the investor is likely to have a lot of funds to back it up due to the backing of a third-party funder. This knowledge may therefore cause New Zealand to settle more often. As New Zealand is a relatively small country, the prospect of entering into arbitration with a party who is backed by an established third-party funder may be daunting: it may be difficult for New Zealand to match the level of funding that some of the larger international third-party funding companies can provide.

\section{Issue 2: Disclosure of the Details of a Third-Party Funding Agreement}

The issue of whether a party should be obliged to disclose not merely the existence of a funding arrangement with a third party but also the details of their agreement is also rife with controversy in the international arbitration community. There is currently no consensus at an international level about whether such details should be disclosed and, if so, whether all the details of the funding arrangement can be disclosed or only certain aspects of it. The International Bar Association's revised 2014 Guidelines mentioned above do not require the parties to disclose the terms of the funding agreements. ${ }^{168}$ However, more clarity may be helpful in this area. This issue is another one where the international

168 "IBA Guidelines and Rules", above n 153. 
community may be able to look to domestic law for assistance in regulation. Australia and New Zealand in particular have looked at this issue.

Australian courts have declined to order a party receiving third-party funding to disclose the full funding agreement to the other party. ${ }^{169}$ Instead, Australian courts have ordered funded parties to disclose redacted copies withholding the funder's identity, several terms, and the amount of funding. ${ }^{170}$ These courts state that nondisclosure upholds the administration of justice by preventing the other party from accessing information that may provide tactical assistance. ${ }^{171}$

In New Zealand, both the cases of Houghton $v$ Saunders and the Waterhouse case discussed above considered whether the details of a third-party funding agreement should be disclosed. ${ }^{172}$ The aforementioned 2008 draft Class Actions Bill and new draft Rules also discuss the terms of funding agreements. ${ }^{173}$ The new draft Rules state that an application for a class action order must be accompanied by affidavit evidence, including "general information as to any arrangements, in place or prospective, for funding the proposed class action (including the terms of any agreement or proposed agreement with a litigation funder)". ${ }^{174}$ The defendants must also receive this application. ${ }^{175}$ Although these rules do not oblige the plaintiff to provide the defendant with a copy of the entire funding

\footnotetext{
${ }^{169}$ Houghton v Saunders CIV-2008-409-000348-Nov at [29].

170 Weston v Publishing and Broadcasting Ltd [2010] NSWSC 1288; Re Kingsheath Club of the Clubs Ltd (in liq) [2003] FCA 1034; Elfic Ltd v Macks [2000] QSC 18.

171 Ibid.

${ }^{172}$ Houghton v Saunders, above n 169; Waterhouse v Contractors Bonding Limited, above n 1.

173 Draft High Court Amendment (Class Actions) Rules 2008, r 34.7.

174 Ibid.

175 Ibid.
} 
agreement, they do require the plaintiff to disclose "general information" about the terms of the agreement. ${ }^{176}$

In Houghton $v$ Saunders, the High Court found that the plaintiff did not have to disclose to the defendant the entire funding agreement and the underlying litigation policy. ${ }^{177}$ In this case, the plaintiff had provided the full funding agreement to the court and the defendant had received a brief outline of the agreement. ${ }^{178}$ However, the Court did not hold that the plaintiff will never have to provide the full funding agreement to the defendant. ${ }^{179}$ Further, Houghton $v$ Saunders is unlikely to be overly instructive for future cases. First, like the Class Actions Bill and draft Rules, the case only addressed class actions. ${ }^{180}$ Second, one commentator observed that "[a]t best, this case illustrates that the parameters of disclosure will likely depend on the facts of that particular case, the reason for the disclosure, what information is to be disclosed, and to whom". ${ }^{181}$ However, this case is helpful in that it warns parties that a funding agreement may have to be shared with the court, although possibly not to another party. ${ }^{182}$

In Waterhouse, which applies only to individual actions, the Supreme Court held that there is no general duty of disclosure of the funding agreement: disclosure of some of the terms of the funding agreement will only ever be required where the other party makes an application to which the terms of the funding arrangement are applicable. ${ }^{183}$ The

\footnotetext{
${ }^{176}$ Houghton v Saunders CIV-2008-409-000348-Nov at [27].

177 Ibid, at [211].

${ }^{178}$ Maya Steinitz “A Model Litigation Finance Contract” Litigation Finance Contract 11 Feb 2013

$<$ http://litigationfinancecontract.com>.

179 Ibid.

${ }^{180}$ Ibid.

181 Ibid.

182 Ibid.

${ }^{183}$ Waterhouse v Contractors Bonding Limited, above n 1, at [73].
} 
purpose of this disclosure is to allow the other party to make an informed decision about whether to proceed with the application. ${ }^{184}$

The terms of the funding agreement that Waterhouse may require disclosure of are: ${ }^{185}$

i) the identity and location of litigation funder; and

ii) its amenability to the jurisdiction of the New Zealand courts if that is relevant.

The earlier Court of Appeal decision included two other factors that may require disclosure: ${ }^{186}$

i) the funder's financial standing/viability; and

ii) the terms on which funding can be withdrawn and the consequences of withdrawal.

However, the Supreme Court held that the funded party under no circumstances has to provide details of these last two factors. ${ }^{187}$ This is because both pieces of information could provide the other party with a "tactical advantage" as the other party could attempt to use that knowledge to have the funded party's funding prematurely withdrawn. ${ }^{188}$ In terms of the litigation funder's financial situation, the Court noted that the concern that the non-funded party may be left "high and dry" did not justify disclosure as this was a possibility in all litigation, not just litigation that involves a

\footnotetext{
${ }^{184}$ Helen Arathimos, above n 16.

${ }^{185}$ Waterhouse v Contractors Bonding Limited, above n 1, at [76].

${ }^{186}$ Ibid, at [8].

${ }^{187}$ Ibid, at [70]-71].

${ }^{188}$ Ibid.
} 
third-party funder. ${ }^{189}$ Further, that if the other party wishes to secure their interest in the dispute that party can apply for security for costs. ${ }^{190}$

The international arbitration community may be able to draw on some aspects of these cases. Both the New Zealand and Australian courts are generally against providing another party with the entire funding agreement, preferring instead to give the other party a sparser version of the agreement. This is probably a wise approach considering the reasoning in Waterhouse, which observed that providing more detailed information about the funding agreement could give the defendant with a "tactical advantage". ${ }^{191}$ As it seems likely that the international arbitration community will accept either this or similar reasoning and allow some level of information to be disclosed, the real issue then is what terms will be disclosed. In New Zealand, both the draft Rules and Houghton $v$ Saunders advocate an approach of a general outline of all the terms. Conversely, the Australian courts and Waterhouse prefer to only disclose a few select terms.

The inconsistency between these cases shows that the international arbitration community cannot simply uplift the domestic law in this area and apply it at an international level. Although the domestic cases may be helpful in suggesting to the international community that perhaps some terms should be disclosed, the terms that the courts have allowed to be withheld and required to be disclosed are not necessarily helpful at an international level. For example, the amenability of a funder to the

\footnotetext{
${ }^{189}$ Waterhouse v Contractors Bonding Limited, above n 1, at [55] and [71].

${ }^{190} \mathrm{Ibid}$, at [70] and [76].The Court stated that the funded party does not have to disclose the terms on which funding may be withdrawn with the proviso that the disclosure of these terms may be relevant if the terms give the litigation funder any legal control over the action.

${ }^{191}$ Ibid, at [70]-[71].
} 
jurisdiction of a certain domestic court is not relevant an international level. The international community therefore has a long way to go in regard to this issue as it may be less appropriate to build on a foundation of domestic law here.

How the international arbitration community decides to deal with this issue will affect New Zealand's experience in international arbitration by influencing how much knowledge New Zealand will have about what it is up against in any given arbitration. If a stricter approach is taken to third-party funding and all the terms of a funding agreement have to be disclosed, New Zealand will be in a better position to know what to expect from the arbitration. If some key terms are left out, it will be harder for New Zealand to gauge what it can expect from the arbitration. For example, a funded party may not have to disclose to New Zealand in what circumstances its funding might be withdrawn, which leaves New Zealand unaware as to whether it will be able to successfully retrieve the payment due from a costs award against the other party. Based on domestic law, it seems unlikely that the international arbitration community will require disclosure of the full agreement. But exactly what terms are disclosed will dictate how knowledgeable and therefore how prepared New Zealand will be before entering international arbitrations.

\section{Issue 3: Security for Costs and RSM v St Lucia}

A third issue in third-party funding in international arbitration is whether a tribunal can order security for costs and, if so, in what circumstances a tribunal should do so. In many instances, tribunals have simply refused to do so. ${ }^{192}$ However, just as the

\footnotetext{
${ }^{192}$ Carlos Gonzalez-Bueno and Laura Lozano “Third-Party Funding Again Under the Spotlight” 8 Oct 2014 Kluwer Arbitration Blog <http://kluwerarbitrationblog.com>.
} 
international community may have started to believe that security for costs would never be granted, the case of RSM v St Lucia was decided. ${ }^{193}$ This controversial decision attracted a large amount of commentary and criticism from the international community. ${ }^{194}$ The St Lucia decision was the first decision to order security for costs in an investor-state dispute. ${ }^{195}$ The ICSID based their decision to order security for costs on three elements: the claimant's proven non-payment background, its conceded lack of funds and the involvement of a third-party funder. ${ }^{196}$ The decision has sparked discussion about whether states engaging in international arbitration should be able to get security for costs in instances where the claimant is being funded by a third-party funder, unless the claimant has a satisfactory amount of funds. ${ }^{197}$

Because the St Lucia decision was such a controversial one, the dispute will be described in detail to illustrate the steps in the decision-making process that led to such a criticized and contentious outcome. As the award of security for costs here was made due to certain "exceptional circumstances" in the case, considering these circumstances allows for a better understanding of how future tribunals may approach the issue of awarding security for costs. Further, an analysis of the different reasoning of different tribunal members in reaching the decision will highlight some of the varying views in the international community on awarding security for costs.

\footnotetext{
${ }^{193}$ Carlos Gonzalez-Bueno and Laura Lozano, above n 192.

${ }^{194}$ Ibid.

195 Ibid.

${ }^{196}$ Ibid.

${ }^{197}$ Ibid.
} 
The background dispute between the parties in St Lucia began when St Lucia granted the claimant an exclusive oil exploration license. ${ }^{198}$ However, after disputes about the boundary of the exploration area and involvement of Saint Lucia's prime minister, the parties arguably varied and extended the exploration agreement. ${ }^{199}$ The dispute at issue in the case arose when the claimant later tried to assert its right under the agreement to explore the area. ${ }^{200}$ The claimant argued that the agreement was still in force, or alternatively that the respondent has terminated the agreement by breaching it and the claimant therefore deserves to be reimbursed for damages. ${ }^{201}$ Conversely, the respondent argued for an award to dismiss the claimant's claims and a declaration that the agreement between the respondent and the claimant had either expired or could not be enforced, which would therefore mean that the respondent would have no obligations in regard to the plaintiff. ${ }^{202}$

The real dispute at issue was whether the respondent could be successful in seeking an order to require the claimant to post the amount of US\$750,000 as security for costs. ${ }^{203}$ A majority of the tribunal found for the respondent and ordered the claimant to post security for costs. ${ }^{204}$ One member of the tribunal dissented. ${ }^{205}$ As above, this was a highly unexpected outcome.

In seeking an order for costs, the respondent argued that Article 47 of the ICSID Convention and the ICSID Arbitration Rule 39 gave the Tribunal jurisdiction

\footnotetext{
${ }^{198}$ RSM Production Corporation v Saint Lucia, ICSID case No. ARB/12/10, IIC 655 (2014), 13 August 2014 at [17].

${ }^{199}$ Ibid, at [18]-[22].

${ }^{200}$ Ibid, at [23].

${ }^{201}$ Ibid.

202 Ibid.

203 Ibid, at [24].

${ }^{204}$ Ibid, at [90].

205 Ibid, at [1] per Edward Nottingham.
} 
and the ability to order the claimant to post security for costs. ${ }^{206}$ Article 47 of the ICSID Convention reads:

Except as the parties otherwise agree, the Tribunal may, if it considers that the circumstances so require, recommend any provisional measures which should be taken to preserve the respective rights of either party.

The ICSID Arbitration Rule 39(1) reads very similar to Article 47:

(1) At any time after the institution of the proceeding, a party may request that provisional measures for the preservation of its rights be recommended by the Tribunal. The request shall specify the rights to be preserved, the measures the recommendation of which is requested, and the circumstances that require such measures.

The respondent accepted that no ICSID tribunal had in the past made an order for security for costs. ${ }^{207}$ Nevertheless, the respondent argued that certain exceptional circumstances in the present case warranted a successful application for security for costs. ${ }^{208}$ The tribunal agreed that exceptional circumstances in this case supported an award of security for costs. ${ }^{209}$

The respondent pointed to several different circumstances as to why it thought that an award of security for costs was appropriate in this instance, but in the end a majority of the tribunal held that three main factors present in this case were responsible for the tribunal accepting the respondent's request. ${ }^{210}$ First, the claimant

\footnotetext{
${ }^{206}$ RSM Production Corporation v Saint Lucia, above n 198, at [26].

${ }^{207}$ Ibid, at [27].

${ }^{208}$ Ibid.

${ }^{209}$ Ibid, at [86].

${ }^{210}$ Ibid.
} 
had a history of not paying costs in other ICSID proceedings that it was involved in. ${ }^{211}$ In this regard, the respondent drew attention to the fact that since not complying with costs orders in previous ICSID proceedings, the claimant had still gone on to instigate several other arbitration and litigation actions, suggesting that the claimant is likely to initiate proceedings even when it knows that it may not be able to pay a costs award that is ordered against it. ${ }^{212}$

Second, the claimant had itself accepted that it had scarce financial means and stated that it "hope[d] to be in a position to honor a possible costs award issued against it". ${ }^{213}$ Third, the involvement of a third-party funder in the case of the claimant was relevant. ${ }^{214}$ The respondent argued that a third-party funder might be willing to fund the instigation of the proceedings but that there is a danger to the respondent that the third-party funder might commit what the respondent called an "arbitral-hit-and-run", where the third-party funder would not agree to adhere to the claimant's responsibilities under any eventual costs order. ${ }^{215}$

The claimant first argued that the Tribunal had no jurisdiction under Article 47 of the ICSID Convention and the ICSID Arbitration Rule 39(1) to order security for costs. $^{216}$ In the alternative, the claimant further argued that even if the tribunal does have jurisdiction to make an order for security for costs, exceptional circumstances must be present for such an order to be justified, and that these exceptional

\footnotetext{
${ }^{211}$ RSM Production Corporation v Saint Lucia , above n 198, at [30].

${ }^{212}$ Ibid, at [32].

${ }^{213}$ Ibid, at [40].

${ }^{214}$ Ibid, at [86].

${ }^{215} \mathrm{Ibid}$, at [33].

${ }^{216}$ Ibid, at [38].
} 
circumstances were not present here. ${ }^{217}$ The claimant then proceeded to give reasons as to why exceptional circumstances justifying an order for security for costs were not present in this instance. ${ }^{218}$ Lastly, the claimant made known its belief that the respondent was also receiving funding for this dispute from a third-party funder, thus the respondent would not actually experience an instant detriment if the claimant did not pay costs. ${ }^{219}$ Instead, the claimant argued that an order for security for costs would simply act to advantage the third-party funder that was funding the respondent; the respondent is not susceptible to a greater risk because of its agreement with a thirdparty funder. ${ }^{220}$

In considering these arguments, the tribunal accepted that neither Article 47 of the ICSID Convention nor the ICSID Arbitration Rule 39 specifically dealt with the tribunal's ability to order security for costs, but noted that most ICSID tribunals have concluded that the tribunal possesses the ability to make such an order in exceptional circumstances. ${ }^{221}$ The majority justifies these wide readings by stating that the ICSID Convention was drafted in 1965 when "issues such as third-party funding and thus the shifting of financial risk away from the claiming party were not as frequent, if at all, as they are today". ${ }^{222}$

More importantly, the tribunal considered that the fact that the claimant was being funded by a third-party funder reinforced the respondent's concern that the claimant might not adhere to a costs award that was ordered against it; the tribunal

\footnotetext{
${ }^{217}$ RSM Production Corporation v Saint Lucia , above n 198, at [39].

${ }^{218} \mathrm{Ibid}$, at [40]-[43].

${ }^{219} \mathrm{Ibid}$, at [44].

${ }^{220}$ Ibid.

${ }^{221} \mathrm{Ibid}$, at [52].

${ }^{222} \mathrm{Ibid}$, at [56].
} 
noted that it was "doubtful" whether the third-party funder would otherwise volunteer to take on the duty of paying such an award. ${ }^{223}$ The tribunal found that, in these circumstances, it would be unfair to place a risk on the respondent that the third-party may not accept the responsibility of honoring a potential costs award that favoured the respondent. ${ }^{224}$ This argument highlights an important policy point as to why security for costs should perhaps sometimes be awarded in international arbitration. However, one counter argument to the court's reasoning here is that unfairness to the respondent may need to be balanced with access to justice for the claimant. ${ }^{225}$ The tribunal here failed to consider whether it may be more important that the claimant receives sufficient funding from a third-party to bring a potentially meritorious claim than whether the respondent receives security for costs, which may leave the tribunal's reasoning to feel somewhat incomplete.

Tribunal member Gavan Griffith agreed with the outcome that the majority of the tribunal came to but provided different assenting reasons for his conclusion. ${ }^{226}$ Griffith agreed with the majority judgment that the tribunal can make security for costs orders in exceptional circumstances and that the facts of the present case were exceptional, and therefore justified an order for security for costs. ${ }^{227}$ However, instead of giving three different reasons why the facts of this case were exceptional, with a focus on the

\footnotetext{
${ }^{223}$ RSM Production Corporation v Saint Lucia, above n 198, at [83].

${ }^{224}$ Ibid.

${ }^{225}$ Nieuwveld and Shannon, above n 9, at 108.

${ }^{226}$ RSM Production Corporation v Saint Lucia , above n 198, at [1] per Gavan Griffith.

${ }^{227}$ Ibid.
} 
respondent's “one-off” non-payment history, Griffith focused wholly on the third-party funding issue. ${ }^{228}$

Griffith noted that it was becoming a common problem that third-party funders are funding claims, effectively as a joint venture to receive a portion of the claimant's success, yet third-party funders do not have to risk more than the costs they have already incurred if the claimant is unsuccessful where security for costs orders are not made. ${ }^{229}$ Griffith states that such a business setting is "the gambler's Nirvana: Heads I win, and Tails I do not lose". ${ }^{230}$ As a matter of policy, Griffith holds that such funders should have to bear the same risks as the actual claimant does in supporting a claimant to take a claim. ${ }^{231}$ Griffith states that his "determinative proposition is that once it appears that there is third-party funding of an investor's claims, the onus is cast on the claimant to disclose all relevant factors and to make a case why security for costs orders should not be made". ${ }^{232}$ Like the majority, Griffith does not address the issue of a claimant's increased access to justice where third-party funding is available, and what effect ordering security for costs may have on this access.

The dissenting judge, Edward Nottingham, argued mostly that the language of Article 47 of the ICSID Convention and Rule 39(1) of the ICSID Arbitration Rules do not support the conclusion that security for costs can be ordered in this instance. ${ }^{233}$ However, of interest to this paper is his articulation of some of the issues that he believes that thirdparty funding of ICSID arbitrations may raise:

\footnotetext{
${ }^{228}$ RSM Production Corporation v Saint Lucia, above n 198, at [11] per Gavan Griffith .

229 Ibid, at [12].

230 Ibid, at [13].

231 Ibid, at [14].

232 Ibid, at [18].

${ }^{233}$ RSM Production Corporation v Saint Lucia, above n 198, at [1] per Edward Nottingham.
} 
"Should third-party funding ever be permitted? If so, under what conditions? Is such funding a legitimate tool allowing the pursuit of meritorious claims which otherwise could not be brought? Or is it a form of reprehensible barrarty? What information about the nature of the funding or the identity of the funder should be relevant? What are the terms of the funding contract? Indeed, how is third-party funding defined? Would an insurance contract under which a State financed the defense of a case fit the definition?"

The attitudes shown towards third-party funding in the majority and assenting opinions, and criticisms of these opinions, may assist in trying to determine what the attitude towards third-party funding will be in an instance of investor-state arbitration that New Zealand might have to partake in. A court or tribunal that treads carefully in regard to the issue of third-party funding is likely to be more open to imposing restrictions on aspects of third-party funding or to taking measures to protect a party from the other party's use of third party funding. Thus the more skeptical that previous ICSID judgments and any accompanying commentary are about third-party funding, the more likely it is that a generous approach will be taken to awarding security for costs against a party funded by a third-party funder. In turn, such a generous approach will make it easier for states to find themselves up against a third-party funder in international arbitration as states are less likely to be unable to retrieve costs at the end of an arbitration proceeding.

However, it is unclear that states up against an investor will be awarded security for costs on a regular basis. First, as emphasized in the St Lucia decision, exceptional circumstances will probably have to be present before a court or tribunal will award security for costs. ${ }^{234}$ Second, the St Lucia decision was the first decision to award security

${ }^{234}$ RSM Production Corporation v Saint Lucia, above n 198, at [87]. 
for costs in an investor-state dispute, which suggests it will be a rare occurence. ${ }^{235}$ Third, the St Lucia decision has been criticized, which may have an influence on the approach that later courts and tribunals will have in regard to awarding security for costs in investor-state disputes.

Some of the main criticisms of the St Lucia decision are aimed at the beliefs that the majority and the assenting judgment appear to take for granted. ${ }^{236}$ One commentator listed four beliefs that the decision was probably based on and proceeded to argue that these beliefs were unfounded. ${ }^{237}$ The four beliefs are as follows:

1) Funders do not carefully assess, review and consider the claims they fund; they gamble.

2) Come what may, funders do not lose. They are always winners.

3) Had the founders of the Convention foreseen the emergence of third party funding, they would have required automatic orders for security for costs in funded cases.

4) Because of the nature of their business, funders should take a larger risk than that of the possibility of losing the entire investment in arbitral proceedings when the average total costs are of USD8 million. ${ }^{238}$

The commentator that identified these four beliefs argues that both the majority and the assent overlooked the following key facts that undermine these beliefs to some extent. ${ }^{239}$ First, professional funders only fund claims after careful investigation into the claim and with the assistance of highly proficient practitioners; professional funders are not

${ }^{235}$ Carlos Gonzalez-Bueno and Laura Lozano, above n 192.

${ }^{236}$ Yasmin Mohammad "A Partial Commentary of the RSM Production Corporation v. Saint Lucia Decision on Security for Costs" ICCWBO 11 Sep 2014 <emailing.iccwbo.org>.

${ }^{237}$ Ibid.

${ }^{238}$ Ibid.

${ }^{239}$ Ibid. 
gamblers. ${ }^{240}$ Second, as many as half of the claimants that seek third-party funding for their claims do actually have the financial resources to fund their own claim, but they simply make a financial choice to avoid having their liquid capital be caught up in financing a dispute and instead to prefer to invest that capital in other investments. ${ }^{241}$

Third, if a third-party funder has to provide security for costs, this significantly increases the cost of the investment for a third-party funder; freezing an immense amount of money for the duration of the entire proceeding is expensive. ${ }^{242}$ Moreover, an application for security for costs is likely to lengthen the proceedings as well as make the proceedings more expensive. ${ }^{243}$ Fourthly, many established funders include After the Event Insurance (ATE insurance), which the claimant pays a premium for and which creates an indemnity for the other party's costs in the instance that the claimant is unsuccessful. ${ }^{244}$ Due to the inconvenience of having to be part of proceedings for security for costs, the commentator make two recommendations for the situation where either a claimant or a respondent seeks security for costs in a court or tribunal proceeding: that in the case of an abusive claim a claimant or respondent should have to remunerate the funds that have been immobilized at a sufficient rate; and, that the party claiming security for costs should immediately repay the party who had to defend the application in the instance where security for costs is not granted. ${ }^{245}$

In light of these facts, the commentator makes a good point that routinely awarding unremunerated security for costs when half of potential claimants need a third-party funder,

\footnotetext{
${ }^{240}$ Yasmin Mohammad, above n 236.

${ }^{241}$ Ibid.

${ }^{242}$ Ibid.

${ }^{243}$ Ibid.

${ }^{244}$ Ibid.

${ }^{245}$ Ibid.
} 
loan from the bank or a mortgage in order to fund a claim, is likely to obstruct access to justice for some of these claimants. ${ }^{246}$ The issue of access to justice was largely ignored in the St Lucia decision. Commentators also note that investment treaty dispute mechanisms were created to guard those parties that needed guarding, namely, the investors. ${ }^{247}$ If investors constantly have to pay security for costs in the event that they are funded by a third-party funder, it will greatly increase the costs of pursuing a claim after obtaining third-party funding, which may defeat the purpose of allowing third-party funding in international arbitration: to increase the likelihood that meritorious claims are brought to a court or tribunal. ${ }^{248}$ From this commentator's arguments, the conclusion can be drawn that the main drawbacks of a decision like St Lucia are that it makes it more difficult for investors to use third-party funding, which may create access to justice issues.

Many have called for regulation in this area of security for costs. ${ }^{249}$ The call for regulation is mainly due to the potential of the St Lucia decision to create uncertainty for the funding market. ${ }^{250}$ As St Lucia was the first ruling to award security for costs against a claimant with a third-party funder in investor-state arbitration, not all third-party funders may have previously considered such an award to be a possibility. ${ }^{251}$ The dissenting tribunal member in St Lucia stated that "the general concerns about third-party funding and security for costs can and should be addressed by the Administrative Council in its rulemaking capacity, if there is a problem that needs to be dealt with". ${ }^{252}$ One way to mitigate

\footnotetext{
246 Yasmin Mohammad, above n 236.

247 Ibid.

248 Ibid.

${ }^{249}$ Egemen Egemenoglu “Overreaction or Creation of Awareness: Major Challenge On Decisions on Security For Costs" 8 Oct 2014 Mondaq <www.mondaq.com>.

${ }^{250}$ Ibid.

${ }^{251}$ Ibid.

${ }^{252}$ RSM Production Corporation v Saint Lucia, above n 198, at [17] per Edward Nottingham.
} 
this risk without regulation that may be adopted by funders is an increase in care in the selection of arbitrators. ${ }^{253}$ Third-party funders will probably urge claimants to select arbitrators that are less disposed to award security for costs against claimants funded by a third-party funder. ${ }^{254}$ Whether or not the Administrative Council will change the rules to clarify the position as to security for costs remains uncertain, but in the meantime it is likely that third-party funders will simply try to choose arbitrators that are unlikely to award security for costs.

Whether or not security for costs can be awarded against a claimant with a third-party funder will affect the state of New Zealand in international arbitration. If New Zealand finds itself up against an investor in an investor-state arbitration where New Zealand cannot obtain security for costs against an investor who is being funded by a third-party, it increases the chances of New Zealand being left 'high and dry' and unable to retrieve costs in the instance that a third-party funder refuses to pay. The likelihood of security for costs being awarded against a third-party funder is low: St Lucia is the only tribunal that has ever awarded security for costs and it only did so due to "exceptional circumstances" that the tribunal thought were present in the case. This means that New Zealand could very well end up being left to pay its own costs in the event that a third-party funder refuses to adhere to a costs order, in the absence of a security for costs award. The possibility of this occurring is likely to encourage New Zealand to settle when it comes across an investor being funded by a third-party to remove this risk.

${ }^{253}$ Egemen Egemenoglu, above n 249.

254 Ibid. 


\section{Issue 4: Costs Awards Against Third-Party Funders}

Since 1986, the United Kingdom courts have accepted that costs awards can be made against third-party funders. ${ }^{255}$ However, such awards have generally been reserved for exceptional circumstances. ${ }^{256}$ These awards are also more likely to be made against professional, or for-profit, funders, rather than against "pure", or non-profit, funders. ${ }^{257}$ The court in Abraham $v$ Thompson outlined the competing policy factors as to whether a costs award should be made against a third-party funder:

\footnotetext{
"It may be unjust to a successful defendant to be left with unrecovered costs, but the plaintiff's freedom of access to the courts has priority... It is preferable that a successful defendant should suffer the injustice of irrecoverable costs than that a plaintiff with a genuine claim should be prevented from pursuing it." 258
}

However, a recent High Court decision in the United Kingdom has suggested that, if a claim is not successful, a third-party funder will generally be equally accountable to pay the defendant's costs as the funded party. ${ }^{259}$ The Court noted two points to mitigate the harshness of this rule on funders. ${ }^{260}$ First, the 'Arkin cap' will be applied. ${ }^{261}$ This cap limits the funder's liability to the level of funding given. ${ }^{262}$ Second, a funder will only be

\footnotetext{
${ }^{255}$ Aiden Shipping $v$ Interbulk Ltd, The Vimeria (No. 2) [1986] 1 AC 965; Nieuwveld and Shannon, above $n$ 9 , at 107.

256 Nieuwveld and Shannon, above n 9, at 107.

${ }^{257}$ Ibid, at 108.

${ }^{258}$ Hamilton $v$ Thompson [1997] 4 All ER 362; Nieuwveld and Shannon, above $\mathrm{n} 9$ at 108.

${ }^{259}$ Excalibur Ventures LLC v Texas Keystone Inc and others [2014] EWHC 3436 (Comm).

260 "Litigation Funders Ordered to Pay Indemnity Costs" 24 Oct 2014 HSF <http://hsfnotes.com>.

261 Ibid.

${ }^{262}$ Arkin v Borchard [2005] 1 WL 3055.
} 
accountable for the defendant's costs that were sustained from the time of the funder's involvement. ${ }^{263}$

Though the United Kingdom's domestic law is extremely developed in this area, it may not be useful to the international arbitration community. The power of the United Kingdom courts to make a costs order is found in the Supreme Court Act 1981. ${ }^{264}$ However, in international arbitration, an arbitrator has no personal jurisdiction over the funder. ${ }^{265}$ Therefore, an international arbitrator lacks the authority to make a costs order against a third-party funder. ${ }^{266}$ Some have brainstormed ways to get around this problem: ${ }^{267}$

i) providing a clause in the arbitration agreement that a party must disclose that it is using a funder;

ii) requiring the funded party to secure some sort of security to cover the costs should it lose the case; or

iii) allowing the parties to agree in advance to the arbitrator having the authority to issue a costs order against a third-party funder.

However, as none of these suggestions have yet been put into practice, it is not clear whether the international arbitration community will accept any of these suggestions or even whether they will work. However, as the United Kingdom has a clear domestic framework for this issue it is possible that if the third suggestion is used, the international arbitration community may be able to draw on United Kingdom law in deciding whether to issue a costs order against a third-party funder.

\footnotetext{
263 "Litigation Funders Ordered to Pay Indemnity Costs", above n 260.

${ }^{264}$ Nieuwveld and Shannon, above n 9, at 110.

265 Ibid.

266 Ibid.

${ }^{267}$ Ibid.
} 
Whether or not a costs order can be made against a third-party funder, and in what circumstances, could have a huge effect on how the state of New Zealand will fare in international arbitration. If New Zealand is up against another party who is being funded by a third party funder and loses, New Zealand will be faced with the prospect of having to pay their own costs. Due to the size of the country and it's potentially smaller financial budget for arbitration in relation to some other states and even large third-party funders, the state may have to strain its budget to pay its own costs if this happens for several arbitrations. This could in turn undermine New Zealand's bargaining power as it may encourage New Zealand to settle with parties who are funded by a third-party funder.

Some of the above listed ways to get around the problem may be easier for New Zealand to implement considering some of the law's attitudes to third-party funding in New Zealand. As the torts of maintenance and champerty are still technically parts of New Zealand law, some of the suspicious attitudes to third-party funding that these torts brought with them are likely to remain in New Zealand. ${ }^{268}$ With this mindset, it is more likely that the state of New Zealand will be willing to make efforts to put in place various precautions as to the payment of costs in the event of arbitration.

\section{Issue 5: Recovery of Costs by Third-Party Funders}

Another large question mark that has come with the rise of third-party funding in international arbitration is whether third-party funders can recover their costs as part of a costs award.$^{269}$ In countries like Finland, Nigeria, Sweden and Brazil third-party costs are generally not recoverable because these costs are not costs that the claimant has incurred

${ }^{268}$ Waterhouse v Contractors Building Limited, above n 1, at [25].

${ }^{269}$ Daniel Kaldermis and Paula Gibbs, above n 2. 
from the proceedings, and the third-party funder itself has no right to recover its own costs. ${ }^{270}$ However, it is possible that the position at international law may differ.

The International Bar Association's 2014 Guidelines suggest that a third-party providing funding in arbitration "may be considered to bear the identity of [a] party" for the purposes of conflicts of interest in relationships. ${ }^{271}$ These Guidelines may suggest that for some purposes, the claimant and the third-party funder may be viewed as having the same identity. As the reason that third-party funders cannot claim costs in the domestic countries listed above is because the claimant is considered to have a separate identity from the thirdparty funder, the Guidelines may take a different approach to costs.

However, there may be some reasons why it is inappropriate for third party funders to recover costs. Because funding an arbitration is expensive, a third-party funder will undertake extensive due diligence of the case and its likelihood of success before agreeing to a fund a case. ${ }^{272}$ Due to this extensive research, it may seem appropriate for third-party funders to bear any loss as they are a for-profit business that are capable of calculating and planning for the financial risks of their business.

If third-party funders can recover costs, third-party funders will probably be more likely to take on more cases as there is less for third-party funders to lose financially. This may lead to an increasing number of claims, which may cause New Zealand to find itself party to an increasing number of investor-state arbitrations. Moreover, there will be more situations in which the state of New Zealand will have to pay costs.

\footnotetext{
${ }^{270}$ Daniel Kaldermis and Paula Gibbs, above $\mathrm{n} 2$.

${ }^{271}$ IBA Guidelines on Conflicts of Interest in International Arbitration (2014) International Bar Association, 23 Oct 2014 <http://www.ibanet.org>, Guideline (6) and (7).

272 Daniel Kaldermis and Paula Gibbs, above $\mathrm{n} 2$.
} 
$V \quad$ Effect of Third-Party Funding in International Commercial Arbitration on New Zealand

A Overview

As already discussed in this paper, to date third-party funding has only affected New Zealand in the context of domestic litigation. Further, third-party funding in domestic litigation has only occurred on a small scale. To date, there has not yet been much regulation around third-party funding in litigation or in any other context by the courts or by Parliament. Nevertheless, regardless of any future regulation of third-party funding at a domestic level, third-party funding is almost sure to affect New Zealand at an international level due to the prevalence of third-party funding in international arbitration. The growing prevalence of third-party funding in international commercial arbitration will affect all actors in this sphere of dispute resolution. ${ }^{273}$

The area in which the existence of third-party funding in international commercial arbitration may especially affect New Zealand is in the setting of investor-state arbitration. ${ }^{274}$ In New Zealand, investor-state arbitration has become a contentious matter in light of the Trans-Pacific Partnership Agreement (TPPA). The TPPA is a regional freetrade agreement that has not yet been established. ${ }^{275}$ However, if the TPPA is established and it covers investor-state arbitration, it is possible that New Zealand may find itself in arbitration proceedings against an investor that is being funded by a third-party funder. ${ }^{276}$

\footnotetext{
${ }^{273}$ Elizabeth Chan, above n 10.

${ }^{274}$ Ibid.

${ }^{275}$ Ibid.

${ }^{276}$ Ibid.
} 
Even if a particular state or investor does not enlist the services of a third-party funder in arbitration proceedings, that state or investor may encounter a party in arbitral proceedings who has enlisted the services of a third-party funder. ${ }^{277}$ Arbitrators will also be required to rule on issues that may be affected by the existence of a third-party funder being involved, or a particular arbitrator may even be selected by a third-party funder. ${ }^{278}$ This is likely to be the case regardless of whether third-party funding continues to remain legal in a domestic context: the surge in popularity of third-party funding in international arbitration may influence states to permit third-party funding in international arbitration even if third-party funding is not permitted at a domestic level. ${ }^{279}$ For example, Professor Rogers had noted that even though Singapore has strongly prohibited third-party funding in a domestic context, it has made an exception for international arbitration. ${ }^{280}$

\section{B The TPPA and Investor Rights}

As above, the issues currently present in the context of third-party funding in international arbitration and how they are decided will have various effects on how the state of New Zealand is likely to fare in international arbitration. Another factor to consider in discussing how third-party funding in international arbitration affects New Zealand is the TPPA. The TPPA is a regional free trade agreement between New Zealand, the United States, and ten other North American, South American and Asia-Pacific states that is still in progress. ${ }^{281}$ The TPPA would most likely grant investors substantive rights in the context

\footnotetext{
277 Elizabeth Chan, above n 10.

278 Ibid.

279 Ibid.

${ }^{280}$ Catherine Rogers, above n 10, at 5. See also Elizabeth Chan, above n 10.

${ }^{281}$ Elizabeth Chan, above n 10.
} 
of investor-state arbitration. ${ }^{282}$ The effect of investors being granted broad rights under the TPPA may be to increase the leverage of investors against states like New Zealand. If the TPPA does incorporate investor-state arbitration, New Zealand may be up against an investor that has not only received third-party funding in arbitration proceedings but is also protected by expansive rights. ${ }^{283}$ Thus the combination of the increase in third-party funding in international arbitration and the increased protection for investor rights may make investor-state arbitration a lot harder for New Zealand in the future.

However, the TPPA is still a work in progress and it is not certain that investor protections will be included. Whether investors should be granted substantive rights in the TPPA is a contentious issue for several reasons, not least because it may provide investors with increased leverage against states. The contentiousness of this issue was highlighted when in 2012 over a hundred jurists wrote a letter entitled "An open letter from lawyers to the negotiators of the Trans-Pacific Partnership urging the rejection of investor-state dispute settlement". ${ }^{284}$ These jurists were all from countries that had already agreed or were considering agreeing to be part of the TPPA. ${ }^{285}$

In this letter, these lawyers explain why they believe that foreign investor protections and their capability to be enforced through investor-state arbitration should not be included in the TPPA. ${ }^{286}$ Some of the problems that these lawyers identity relate to investor rights and some relate to the current system of investor-state arbitration itself.

\footnotetext{
${ }^{282}$ Elizabeth Chan, above n 10; “An Open Letter From Lawyers To the Negotiators of the Trans-Pacific Partnership Urging the Rejection of Investor-State Dispute Settlement" 8 May 2012 TPP Legal <http://tpplegal.wordpress.com>.

${ }^{283}$ Elizabeth Chan, above n 50.

284 "An Open Letter From Lawyers To the Negotiators of the Trans-Pacific Partnership Urging the Rejection of Investor-State Dispute Settlement", above n 282.

${ }^{285}$ Ibid.

${ }^{286}$ Ibid.
} 
They base their views on the notion of the rule of law. ${ }^{287}$ They note that Australia has stated that it will not succumb to the Investor-State system under a TPPA and other future trade agreements and argue that other countries should follow suit. ${ }^{288}$ However, New Zealand will almost definitely be party to the TPPA if it is concluded, and will therefore be vulnerable to whatever problems may be associated with the TPPA.

Many of the problems that these lawyers identify with foreign investor protections would exacerbate the issues that might arise in investor-state arbitration where a third-party funder is involved. This is because, as above, third-party funding is likely to cause both an increase in the number of arbitration cases taken against states by investors and states are unlikely to be able to take advantage of third-party funding in the same way that investors can. $^{289}$ Therefore the increasing popularity of third-party funding may put investors in a stronger position in terms of international arbitration, whereas third-party funding is unlikely to do the same for states. The combination of the benefits that third-party funding will provide investors and the proposed investor protections in the TPPA may largely disadvantage states in some international arbitration cases. The rule of law issues that the open letter outlines show how the proposed investor protections under the TPPA may further disadvantage states.

The first rule of law problem that these lawyers see with the proposed rights for investors under the TPPA is that these rights may be so expansive that they compromise the

\footnotetext{
287 “'An Open Letter From Lawyers To the Negotiators of the Trans-Pacific Partnership Urging the Rejection of Investor-State Dispute Settlement”, above n 282.

288 Ibid.

${ }^{289}$ Elizabeth Chan, above n 10.
} 
sovereign rights of states. ${ }^{290}$ The TPPA's apparent purpose is to make sure that foreign investors can get compensation if a government takes their real property and the domestic court systems in that country are inadequate to provide an effective remedy. ${ }^{291}$ These lawyers believe that the TPPA goes further than it needs to go in order to protect investors: the TPPA definition of "covered investments" includes not only real property but also other investments such as intangible contract rights. ${ }^{292}$ As well as the rights themselves being expansive, these lawyers are also concerned that these rights will be interpreted generously. ${ }^{293}$

The potential for the rights of foreign investors in the TPPA to be read too widely needs to be put in the context of other investment treaties which also grant substantive rights to investors. $^{294}$ Several recent Free Trade Agreements (FTAs) and Bilateral Investment Treaties (BITs) have also been extended to cover more than real property and have been interpreted generously, with the result that some of these interpretations have protected international corporations' property and economic interests over the right of states to sovereignty. ${ }^{295}$ The fear is that the wide interpretation of these other instruments is indicative of how investor rights in the TPPA will be interpreted, so that the TPPA would result in more importance being placed on the preservation of the financial interests of transnational corporations over states' sovereign rights to make laws in the public

\footnotetext{
290 "An Open Letter From Lawyers To the Negotiators of the Trans-Pacific Partnership Urging the Rejection of Investor-State Dispute Settlement”, above n 282.

${ }^{291}$ Ibid.

${ }^{292}$ Ibid.

${ }^{293}$ Ibid.

${ }^{294}$ Ibid.

${ }^{295}$ Ibid.
} 
interest. ${ }^{296}$ The lawyers claim that, in compromising the sovereign rights of states, granting investors these rights may compromise the ideal of the rule of law. ${ }^{297}$

The second rule of law problem that these lawyers envisage is that granting investors these rights will increase the instances in which foreign investors can take advantage of more rights than domestic firms and investors can under their national law, to the extent that investor rights may interfere with government actions. ${ }^{298}$ Again, this problem is likely to be exacerbated by the increasing use of third-party funding as investors will probably be more likely to assert these rights if they have more financial backing. There have already been instances in which investor's rights have interfered with government actions. For example, under some FTAs and BITs, arbitral tribunals have issued injunctions against government actions. ${ }^{299}$ In one case, an arbitral tribunal ruled that the North American Free Trade Agreement allowed the tribunal to review government measures, like the function of a domestic court and the standing rules of civil procedure, for potential breaches of investor rights. ${ }^{300}$ The interference of expansive investor rights with government and judicial functions is problematic from a rule of law perspective. In New Zealand, if the TPPA is concluded with broad investor rights, it could arguably allow an arbitral tribunal to issue an injunction against government actions. An increase in thirdparty funding is likely to make this occurrence even more probable as third-party funding will give investors increased opportunities to argue their rights.

\footnotetext{
${ }^{296}$ Elizabeth Chan, above n 10; “An Open Letter From Lawyers To the Negotiators of the Trans-Pacific Partnership Urging the Rejection of Investor-State Dispute Settlement”, above n 282.

297 “An Open Letter From Lawyers To the Negotiators of the Trans-Pacific Partnership Urging the Rejection of Investor-State Dispute Settlement", above n 282.

298 Ibid.

299 Ibid.

300 Ibid.
} 
The lawyers argue that the third rule of law issue is the structure of the InvestorState system tribunals, which the TPPA will probably make it easier for investors to get to if wide rights for investors are included. ${ }^{301}$ Their concern is that investment arbitration is currently "not a fair, independent, and balanced method for the resolution of disputes between sovereign nations and private investors". ${ }^{302}$ First, these tribunals permit lawyers to act in a way that would not be ethical for a judge: lawyers can swap between their roles as arbitrators and advocates for investors. ${ }^{303}$ Second, the Investor-State tribunals do not allow non-investor litigants and other affected parties to participate in the system. ${ }^{304}$ Third, there is a perceived issue that these Investor-State tribunals are being used more and more often, not merely as a last resort. ${ }^{305}$ The availability of third-party funding to investors is already likely to increase the number of cases that are taken to international arbitration. Therefore the combination of third-party funding and the wide investor rights in the TPPA means that the problematic structure of the Investor-State system tribunals could be an increasing concern.

In sum, the authors of this open letter believe that there are several rule of law issues currently present in international investment arbitration, including the current structure of the Investor-State tribunals and the wide rights already given to investors. ${ }^{306}$ These lawyers are concerned that including wide investor rights in the TPPA may cause further infringements to the notion of the rule of law. ${ }^{307}$ Further, the rule of law problems

\footnotetext{
301 "An Open Letter From Lawyers To the Negotiators of the Trans-Pacific Partnership Urging the Rejection of Investor-State Dispute Settlement", above n 282.

${ }^{302}$ Ibid.

${ }^{303}$ Ibid.

${ }^{304}$ Ibid.

${ }^{305}$ Ibid.

${ }^{306}$ Ibid.

${ }^{307}$ Ibid.
} 
that this open letter points out will probably be aggravated by the increasing popularity of third-party funding for two main reasons. ${ }^{308}$

First, third-party funding may increase the amount of claims that investors will bring against states as an investors' lack of funds is much less likely to be an issue when they are considering whether or not to take legal action against a state. ${ }^{309}$ Second, an investor that is being backed by a third-party funder may be able to engage in a longer investor-state arbitration than an investor without this backing as third-party funders are likely to have "deep pockets". ${ }^{310}$ Thus the rise of third-party funding will probably mean that there are more claims with a longer duration, making it even more important that the TPPA strikes the correct balance between investor rights and the rights of states. However, the current proposals for comprehensive investor rights to be included in the TPPA are likely to tip the balance in favour of investors in investor-state arbitration. This issue, combined with the fact that the increasing popularity of third-party funding is likely to also advantage investors, may leave states in a difficult position both financially and legally when they are up against an investor in international arbitration.

As New Zealand is likely to be a part of the TPPA, wide investor rights in the TPPA may make investor-state arbitration more difficult for New Zealand for the above reasons. The fact that third-party funders are more reluctant to back states may mean that New Zealand could find itself up against an investor in an arbitration proceeding where the investor is not only backed by a third party but also has wide-ranging rights. In this instance, the rights that the proposed TPPA will confer on investors may mean that states

\footnotetext{
${ }^{308}$ Elizabeth Chan, above n 10.

${ }^{309}$ Ibid.

${ }^{310}$ Ibid.
} 
are at a disadvantage in international arbitration proceedings as the investor that they are up against may not only have a large amount of funds due to third-party funding but may also have a large amount of legal leverage.

\section{Conclusion}

In sum, the increasing popularity of third-party funding in international arbitration has brought with it a whole range of issues for the international arbitration community to deal with. The first main question is whether regulation is needed in the third-party funding industry, and whether domestic law can be of any use to formulating such regulations. Regulation would be useful for increasing certainty. The "true claimant" model that some domestic countries use is likely to be the best base on which to build regulations in international law. Currently, the issues around disclosure of the presence of a third-party funder and the terms of the agreement, security for costs, costs awards and recovery for costs are all controversial and are likely to spark much more debate in the near future.

Whether third-party funding in international arbitration becomes regulated or not, and if so the approach that the international arbitration community takes to these issues, will affect the position that New Zealand is in when it faces investor-state arbitration. As third-party funders are much more likely to back investors than they are states, New Zealand will probably benefit from a stricter approach to third-party funding. ${ }^{311}$

The requirement at international law for third-party funding to be disclosed lends toward a stricter approach and will probably benefit New Zealand by informing the state of what it will be up against in any given arbitration. However, it is not yet clear what

\footnotetext{
${ }^{311}$ Elizabeth Chan, above n 10.
} 
approach the international community will take to ordering any terms of a funding agreement to be disclosed. The more terms that are required to be disclosed, the better position New Zealand will be in to know what to expect from the arbitration.

Security for costs is a more volatile area. Though it seems that security for costs in a dispute where a third-party funder is involved will generally not be ordered based on previous ICSID decisions, the St Lucia decision suggests that a tribunal might award security for costs in "exceptional circumstances". New Zealand can probably expect to generally not be awarded security for costs when entering an international arbitration with an investor being funded by a third-party, meaning that there will probably often be a risk that the third-party funder will pay their client's adverse costs award.

Equally volatile is the debate over whether a costs award can be made directly against a third-party funder. Though domestic jurisdictions like the United Kingdom have very clearly answered yes to this question, there are different factors at play concerning the jurisdiction of an international arbitrator that may make domestic law an unreliable indicator of how the international arbitration community will treat this problem. If costs awards can be made directly against third-party funders, that will decrease the risk of New Zealand having to pay its own costs.

There is also still a large question mark in international arbitration as to whether third-party funders can recover their costs as part of a costs award. There is little jurisprudence on this issue, although there are policy reasons why third-party funders should not be able to do so. If third-party funders can do so, New Zealand might find itself 
paying costs more often and being party to an increasing number of international arbitrations as third-party funders will probably have more incentive to back claimants.

New Zealand may be particularly affected if the international arbitration community takes a lenient approach to third-party funding as New Zealand is also likely to be affected by the potentially wide investor rights in the proposed TPPA. As third-party funders are more likely to support investors than states, New Zealand could face not only the obstacle of entering into arbitration with an investor that is being funded by a third-party funder, but also the obstacle of such investors having extensive rights. ${ }^{312}$

It can be seen that third-party funding in international arbitration is currently in a huge state of flux. The international arbitration community has a large amount of issues to work through and a wide range of directions available to it in which to go. New Zealand will have to wait and see whether the chosen direction is one that benefits it or not.

${ }^{312}$ Elizabeth Chan, above n 10. 


\section{Bibliography}

A Cases

$1 \quad$ Australia

Elfic Ltd v Macks [2000] QSC 18.

Re Kingsheath Club of the Clubs Ltd (in liq) [2003] FCA 1034.

Weston v Publishing and Broadcasting Ltd [2010] NSWSC 1288.

$2 \quad$ New Zealand

Saunders v Houghton [2009] NZCA 610, [2010] 3 NZLR 331.

Re Gellert Developments Ltd (in liquidation) (2001) 9 NZCLC 262,714.

Re Nautilus Developments Ltd (in liquidation) [2000] 2 NZLR 505, (2000) 8 NZCLC 262,235 .

Waterhouse v Contractors Building Limited [2013] NZSC 89.

$3 \quad$ United Kingdom

Aiden Shipping v Interbulk Ltd, The Vimeria (No. 2) [1986] 1 AC 965.

Arkin v Borchard [2005] 1 WL 3055.

Excalibur Ventures LLC v Texas Keystone Inc and others [2014] EWHC 3436 (Comm). 
Hamilton v Thompson [1997] 4 All ER 362

Trendex Trading Corporation v Credit Suissee [1980] [1980 QB 629; [1981 3 All ER 520; 19813 WLR 766 at 654 (CA).

$4 \quad$ International Arbitration Cases

Giovanni Alemanni and others v. Argentine Republic (ICSID Case No. ARB/07/8)

RSM Production Corporation v Saint Lucia, ICSID case No. ARB/12/10, IIC 655 (2014), 13 August 2014.

\section{B Legislation \\ $1 \quad$ New Zealand}

Draft High Court Amendment (Class Actions) Rules 2008, r 34.7.

\section{Journal Articles}

Carlos Gonzalez-Bueno and Laura Lozano "Third-Party Funding Again Under the Spotlight" 8 Oct 2014 Kluwer Arbitration Blog <http://kluwerarbitrationblog.com>.

Daniel Kaldermis and Paula Gibbs "Third-party funding in international arbitration lessons from litigation?" 15 Dec 2014 Kluwer Arbitration Blog $<$ http://kluwerarbitrationblog.com>.

Elizabeth Chan "Funding International Arbitration" [2014] NZLJ 45.

Sean McAnally “Litigation Funding” (2012) NZLJ 361. 


\section{Books}

Lisa Bench Nieuwveld and Victoria Shannon Third-Party Funding in International Arbitration (Kluwer Law International, The Netherlands, 2012).

\section{E Papers and Reports}

Catherine Rogers "Gamblers, Loan Sharks \& Third-Party Funders" (Pennsylvania State University and Dickenson School of Law Legal Studies Research Paper No 51-2013).

IBA Guidelines on Conflicts of Interest in International Arbitration (2014) International Bar Association, 23 Oct $2014<$ http://www.ibanet.org>.

Rules Committee Class Actions for New Zealand (Rules Committee, A Second Consultation Paper, Oct 2008).

Yasmin Mohammad "A Partial Commentary of the RSM Production Corporation v. Saint Lucia Decision on Security for Costs” ICCWBO 11 Sep 2014 <emailing.iccwbo.org>.

\section{F Internet Materials}

Belinda Barclay "Litigation Funding: Coming to A Court Near You" (2008) Lawlink <www.lawlink.co.nz>.

Ben Bigby and Angela Bilbow "Storm Clouds Rising” 11 Dec 2014 Commercial Dispute Resolution <http://www.cdr-news.com>.

Chris Browne and Felicity Monteiro "Supreme Court mandates disclosure of litigation funding agreements" Wilson Harle 10 Dec 2013 < www.wilsonharle.com>.

Christopher Bogart "Third Party Funding in Action: Alemanni v Argentina" 15 Jan 2015 $<$ http://www.burfordcapital.com>. 
Christopher Hodges, John Peysner and Angus Nurse "Litigation Funding: Status and Issues" (Jan 2012) University of Oxford Centre for Socio-Legal Studies <www.csls.ox.ac.uk>.

Egemen Egemenoglu "Overreaction or Creation of Awareness: Major Challenge On Decisions on Security For Costs” 8 Oct 2014 Mondaq <www.mondaq.com>.

Jonathan Wood and Daniel Hemming "Third-Party Funding of Litigation: A Perspective On The International Landscape" Oct $2014<$ http://whoswholegal.com>.

Maya Steinitz "A Model Litigation Finance Contract" Litigation Finance Contract 11 Feb $2013<$ http://litigationfinancecontract.com>.

Rebecca Lowe "Investment Arbitration Claims Could Be 'Traded Like Derivatives" 12 March 2013 International Bar Association <http://www.ibanet.org>.

Reuben Guttman “Litigation is a Rich Man's Game: Finding Justice and Politics of Personalisation” (25 Feb 2014) <www.ibtimes.co.uk>.

Robert Gapes "Litigation Funding” (24 Oct 2012) Simpson Grierson <www.simpsongrierson.com>.

"An Open Letter From Lawyers To the Negotiators of the Trans-Pacific Partnership Urging the Rejection of Investor-State Dispute Settlement" 8 May 2012 TPP Legal $<$ http://tpplegal.wordpress.com>.

“IBA Guidelines and Rules” New Zealand Dispute Resolution Centre <www.nzdrc.co.nz>.

"Litigation Funders Ordered to Pay Indemnity Costs" 24 Oct 2014 HSF $<$ http://hsfnotes.com>. 
"Third-Party Funding in Arbitration" Nov 2014 Australian International Disputes Centre <www.disputescentre.com.au>. 
